\title{
دريدا والتراث القبالي
}

\section{إبراهيم الفيضا}

$$
\begin{aligned}
& \text { الملخص } \\
& \text { يههدف هذا البحث إلى إبراز حضور التصوف اليهودي الباطني "القبالي" في نتاج الفيلسوف اليهودي الفرنسي جاك } \\
& \text { دريدا، وذلك بدراسة العلاقة بين الأدب الفلسفي واللاهوت أولاً، ثم التعريف بالتصوف اليهودي البـاطني المعروف }
\end{aligned}
$$

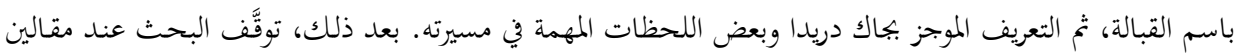

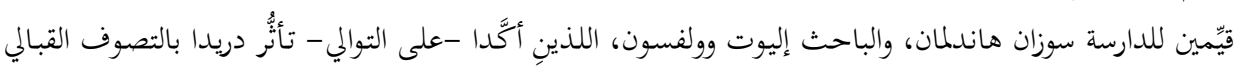

$$
\begin{aligned}
& \text { وتقاطعه معه. وأخيراً، عرض البحث لمثال تطبيقي على ذلك الحضور القبالي في نص دريدا. } \\
& \text { الكلمات المفتاحية: جاك دريدا، التصوف اليهودي، القبالة، التفكيك. }
\end{aligned}
$$

\section{Derrida and the Kabbalistic Heritage \\ Ibrahim Elfida}

\section{Abstract}

This critical study seeks to highlight the influence and presence of the Jewish Mystical tradition, Kabbalah, in the work of the French Jewish philosopher Jacques Derrida. The study initially tries to study the relationship between philosophy, literature, and theology. Then, it provides a short biography of Derrida and a basic definition of the Kabbalah. The paper critically discusses two important works, by Susan Handelman and Elliot Wolfson, on the influence and convergence of Kabbalah and Derrida's work. As a practical example the study shows the presence of Kabbalah in two passages from Derrida.

Keywords: Jacques Derrida, Jewish Mystical tradition, Kabbalah, Deconstruction.

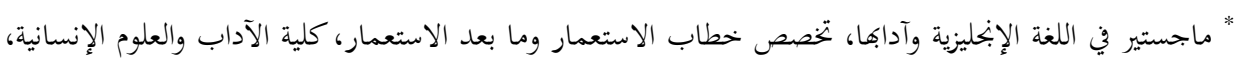

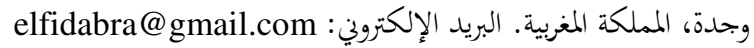

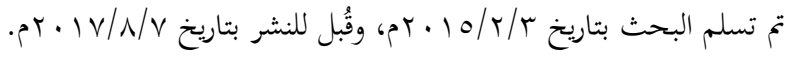




\section{مقدمة:}

$$
\begin{aligned}
& \text { "العالم كله متضمن في التوراة } \\
& \text { ونحن جميعاً متضمنون في التوراة؛ } \\
& \text { وننظر من خلاله } \\
& \text { ولا نظل بالابتعاد عنه." }
\end{aligned}
$$

Abraham Abulafia, 1280

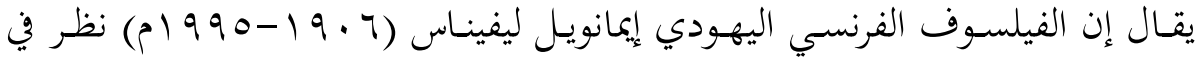

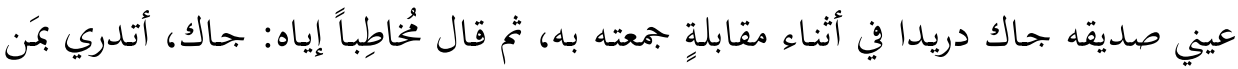
تُذكِّريْ إنك تُذكّربي بقبالي مُهرطِق من القرن السادس عشر ! إن ملاحظة ليفيناس الآنف

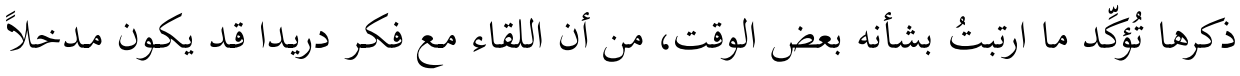

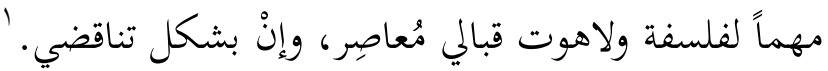
لقــ اهـتم كثير مـن الدارسـين -ومــا يزالـون- سـواء أكـانوا غـربيين أم عربـاً، بنتـاج

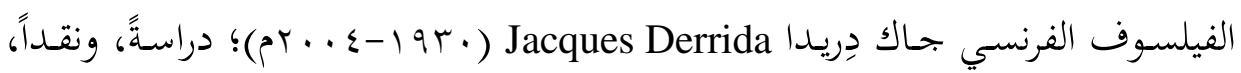

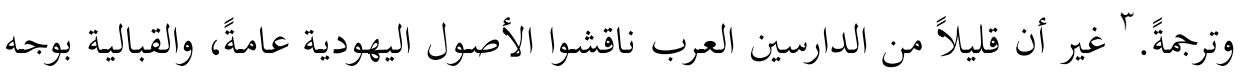

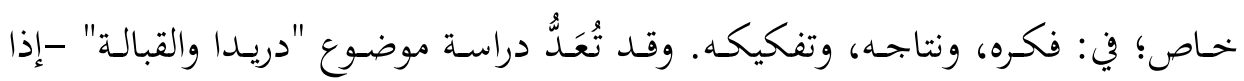

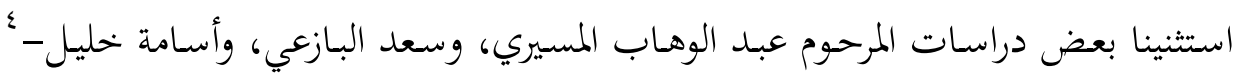

${ }^{1}$ Sanford L. Drob. Kabbalah and Postmodernism: A Dialogue, New York: Peter Lang Publishing, 2009, p.48.

$$
\text { r نذكر على سبيل الجِدِة والتمثيل فقط: }
$$

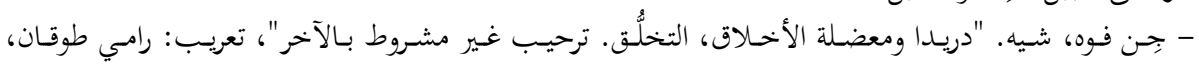

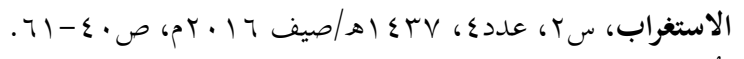

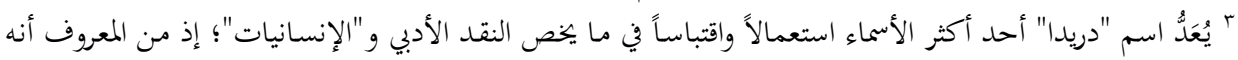
كان يشتغل في حيّز ما بين الفلسفة والآدب.

- البازعي، سعد. المككون اليهودي في الحضـارة الغربيـة، بيروت-الدار البيضـاء: المركز الثقافي العربي، طا، 
مسألةً غير مدروسة بصورة جدية في الفكر العربي عامةً، والنقدي والأدبي منه خاصةً. لقد حاول بعض الباحثين العرب مناقشة هذه الصلة في بعض دراساتم في الموضوع، غير

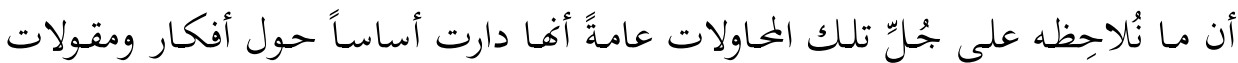

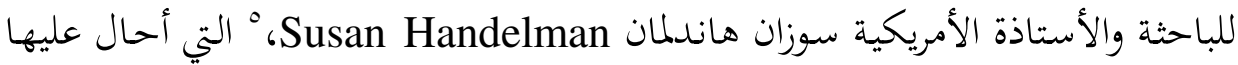

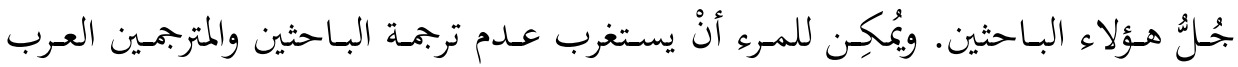

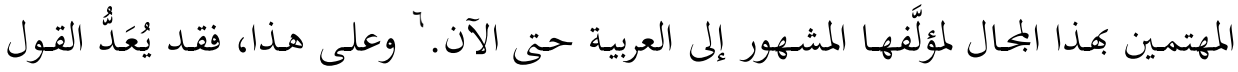

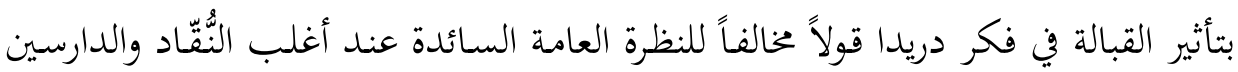
العرب.

ربما لا يسعنا في هذا المقام إلا أنْ نسأل ونُلِح في السؤال، لعلَّنا نظفر في آخر التحليل

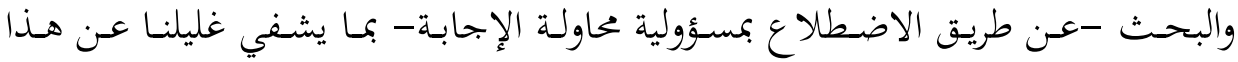

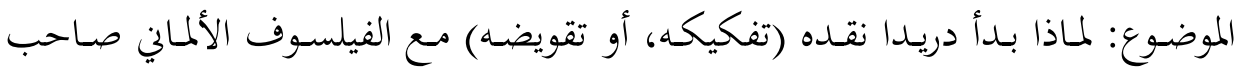

- المسيري، عبد الوهاب. موسوعة اليهود واليهودية والصهيونية، مصر: دار الشروق، 999 ام.

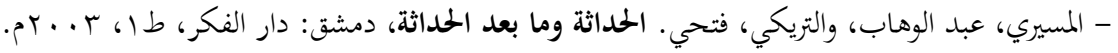

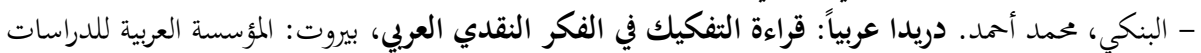

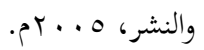

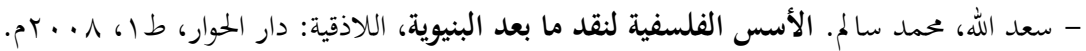

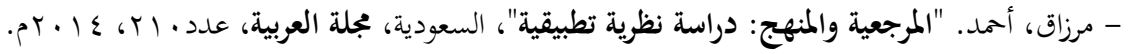

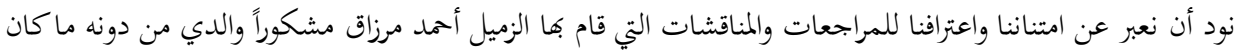
لمدا الدراسة أن ترى النور.

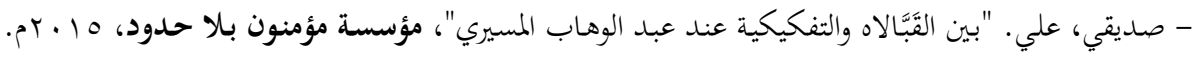

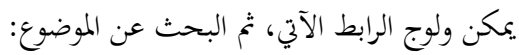

- http://www.mominoun.com/articles.

• سنعتمد هنا على ما قدَّمته الباحثة في كتاها المهم. ولاطَّلاع أكثر على مؤلَّفاقا، يمكن زيارة الموقع الإلكتروني الآتي:

- http://english.biu.ac.il/faculty/handelman-susan

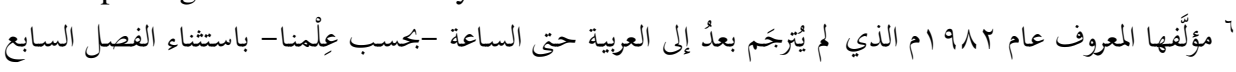
منه، والذي تُرجّم إلى اليابانية والصينية:

- Handelman, Susan. The Slayers of Moses: the Emergence of Rabbinic Interpretation in Modern Literary Theory, Albany: State University of New York Press, 1982, pp. 267. 


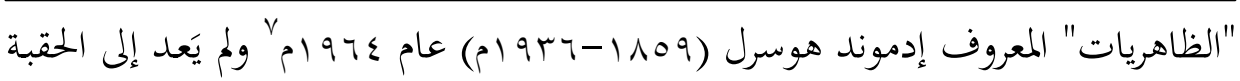
العتيقـة مـع وجـهـ بـارز مـن أعـلام الفلسـفة الغربيـة الكالاسـيكية اليونانيـة (الميتافيزيقيـة)؛

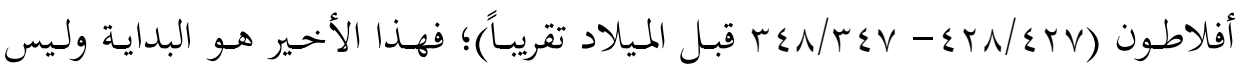
الغايةج؟ لماذا تَّضر في العديد مـن دراسات دريدا ومقالاته أسماء فلاسفة وشعراء وكُّّاب

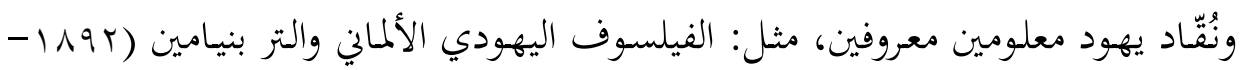

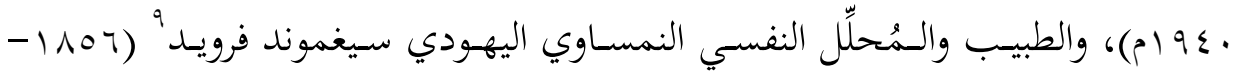

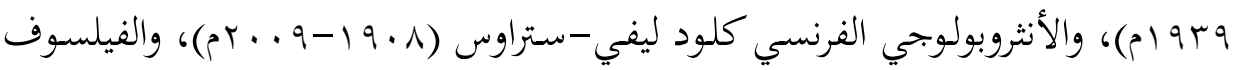

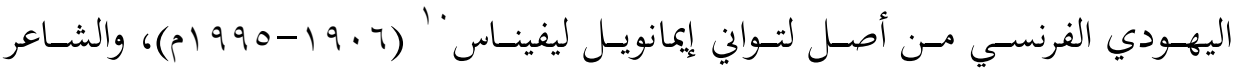

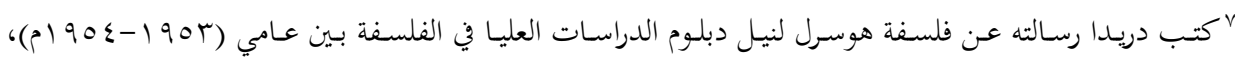

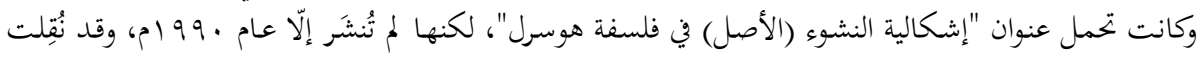

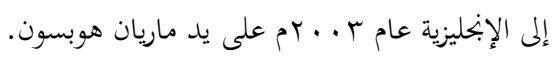

- Le Problème de la genèse dans la philosophie de Husserl, Paris, coll. «Epiméthée »,

PUF, 1990. Rééd. Mémoire pour son diplôme d'études supérieures en philosophie à l'École normale supérieure, en 1953-1954, 2010.

- Derrida, Jacques. The Problem of Genesis in Husserl's Philosophy. Trans: Marian Hobson, Chicago: Chicago University Press, 2003. ^ دريدا، جاك. صيدلية أفلاطون، ترجمة: كاظم جهاد، تونس: دار الجنوب للنشر، 991 ام. ربما شرع دريدا -ببداً

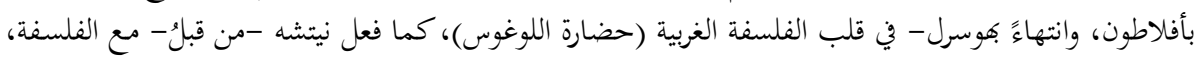

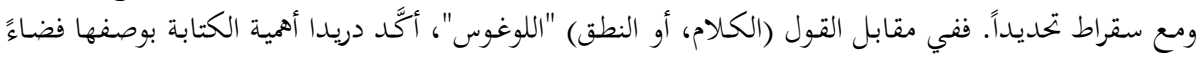
لإمكانية الدلالة. 9 للمزيد من الإطلاع في هدالة الثأن أنظر المر اجث التالية: - Bakan, David. Sigmund Freud and the Jewish Mystical Tradition (New York: Princeton, 1958); $2^{\text {nd }}$ edition 2004.

• ' انتقد ليفيناس انتقاداً شديداً الأنطولوجيا في تاريخ الفلسفة الغربية، وبخاصة مـ خهلال أعمال الفيلسوف الألماني

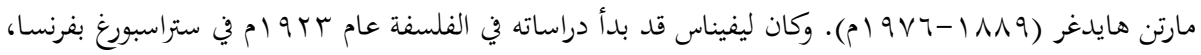

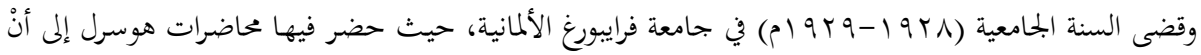

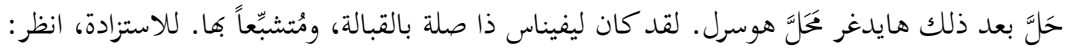

- Wolfson, Elliot R. "Secrecy, Modesty, and the Feminine: Kabbalistic Traces in the Thought of Levinas", The Journal of Jewish Thought and Philosophy, Vol.14, 1-2,

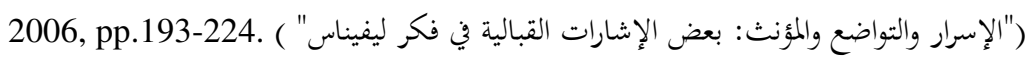

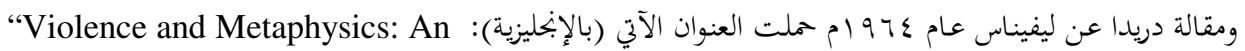
ليفيان "Essay on the Thought of Emmanuel Levinas.” ليفيناس")؛ ثم عاد إليه عام V99 ام في مقالة أخرى حملت عنوان: "Adieu to Emmanuel Levinas". 


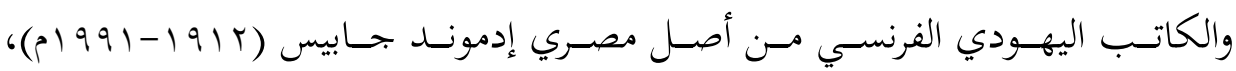
واليهودي الأمريكي والدراس المتخصص في التراث والتاريخ اليهودي، الذي عمل أستاذاً

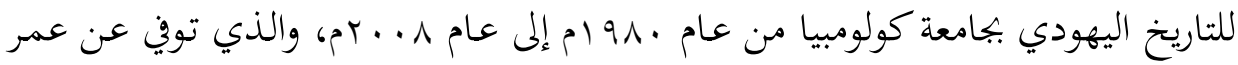

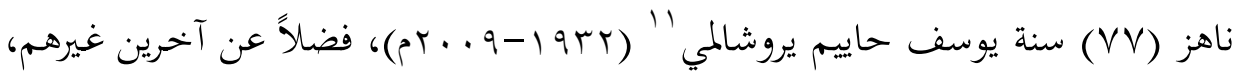
أمثال:

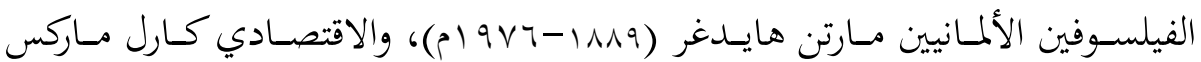

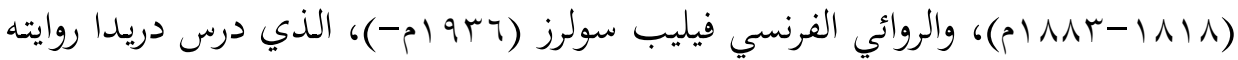

"At this very moment : "مقالة في وداع إيمانوئيل ليفيناس)؛ وتوجد مقالة أخرى لدريدا عن ليفيناس عنواها:

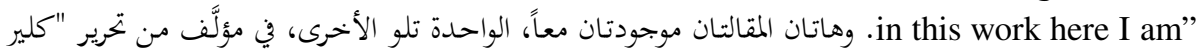
كاتز"، و "لارا تروت". انظر:

- Katz, Claire \& Trout, Lara (eds.). Emmanuel Levinas, Critical Assessments of Leading Philosophers, Levinas, Phenomenology and His Critics, Routledge: London and New York, Vol. 1, 2005. (يمانوئيل ليفيناس: مراجعات نقدية لفلاسفة لأبرز الفلاسفة)

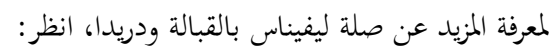

- Del Nevo, Matthew. "Edmond Jabès and Kabbalism after God", Journal of the American Academy of Religion, Vol. 65, No. 2, Summer, 1997, p.406.

- "Torments of an Ancient Word": Edmond Jabès and the Rabbinic Tradition, in: The Sin of the Book: Essays on the Writing of Edmond Jabès, ed. Eric Gould, Lincoln: University of Nebraska Press, 1985, pp.55-91.

- Jacob Meskin, "The Role of Lurianic Kabbalah in the Early Philosophy of Emmanuel Levinas", Levinas Studies, Vol. 2, 2007, pp.49-77. تور القبالة اللوريانية في تشكل باكورة فلسفة إيمانوئيل ليفيناس).

- Derrida, Jacques. Spectres of Marx, Trans: Peggy Kamuf, Routledge, 1994.

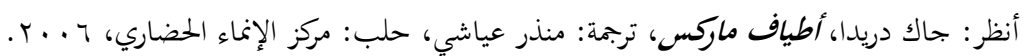

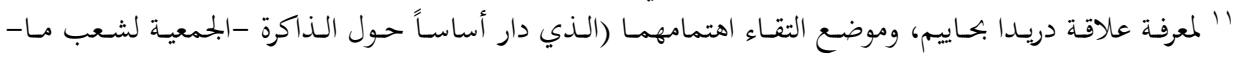

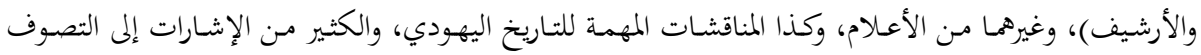

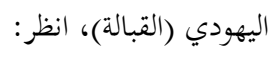

- Yerushalmi, Yosef H. Zakhor: Jewish History and Jewish Memory, Seattle and London: University of Washington Press, 1982. (التاريخ اليهودي والذاكرة اليهودية)

- Yerushalmi, Yosef H. From Spanish Court to Italian Ghetto, Columbia University

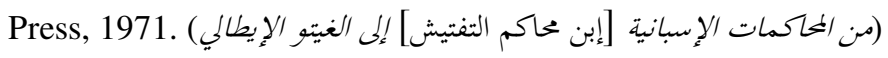

- Myers, David N. and Kaye, Alexander (eds.). The Faith of Fallen Jews, Massachusetts, Brandeis University Press, 2014. 


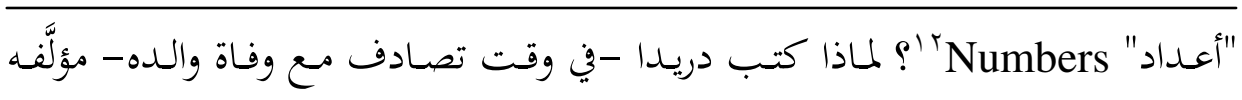

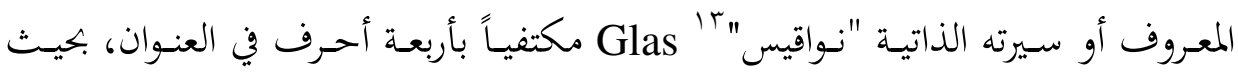

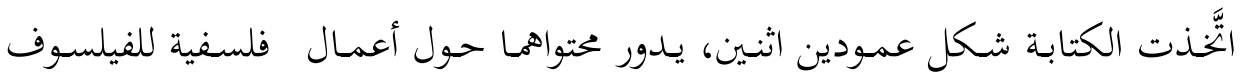

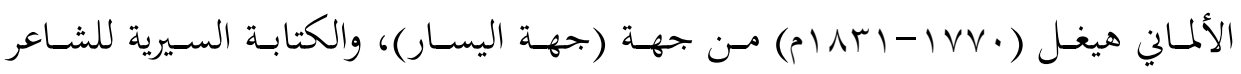

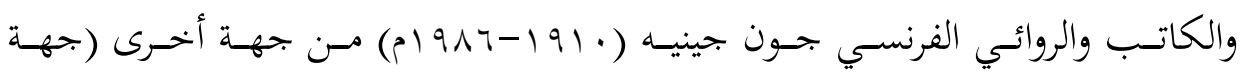

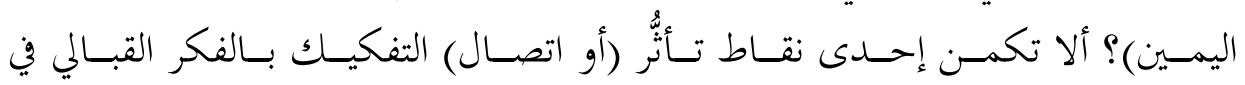

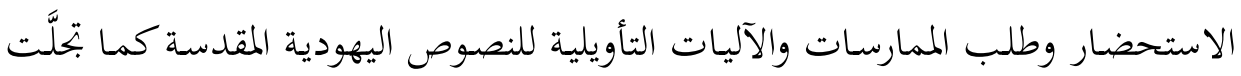
عند أعلامها وحاخاماتا، والتوسُّل بها في دراسة القول الفلسفي والنتاج الأدبي الغربيين؟

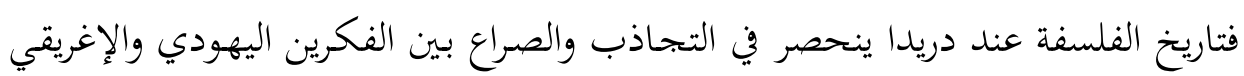
(الملنستي المسيحي)، ويتمثَّل فيهما. إن مسـألة تـأثير اليهوديـة، ولا سـيما القبالـة، في فكـر دريـا قــ طفـت على السطحح

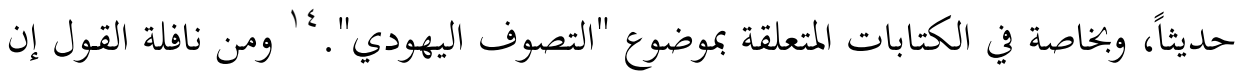
القاموس الصوفي حافل بمفاهيم ومصطلحات، مثل: "الحضور"، و "الحضرة"، و "الرؤية"، و "الحلولية"، ولكـن إيجاد صدى وحضور لافت لها عند أبرز النُّنّاد والمُنظِّرين اللغويين واللسانيين والفلاسفة هو أمر جدير ولإية والاهتمام.

سنحاول في بحثنا دراسة هذا الموضوع، وسبر أغوار تأثير القبالة في فكر الرجل، بحيث

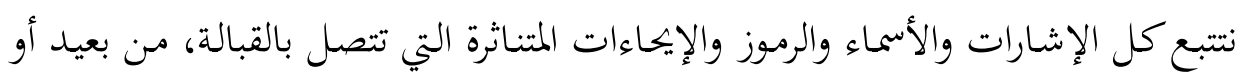
قريب. وقبل الانتقال إلى الموضوع صُلب هذا البحث، ارتأينا الإشارة إلى أربعة أمور نخالها

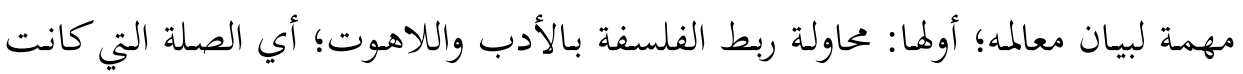

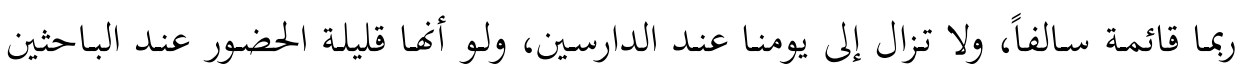

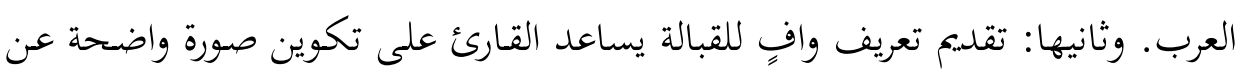

${ }^{12}$ Sollers, Phillipe. Nombres, Paris Editions du Seuil, 1968.

${ }^{13}$ Derrida, Jacques. GLAS, Editions Galilée, 1974.

§' توجد كتابات علدَّة بدأت تتبلور حول هاته المسألة من قبيل كتاب:

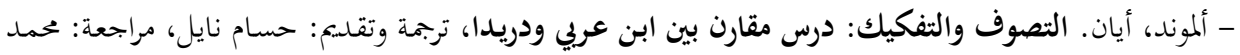

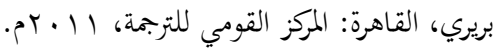




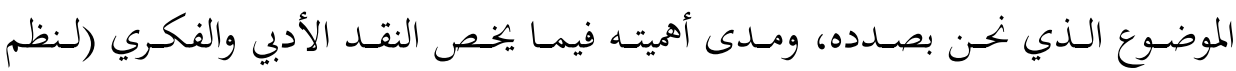

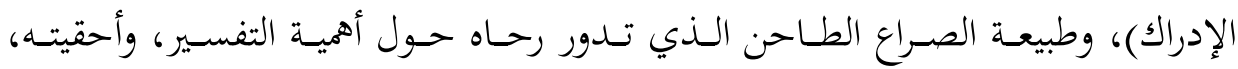

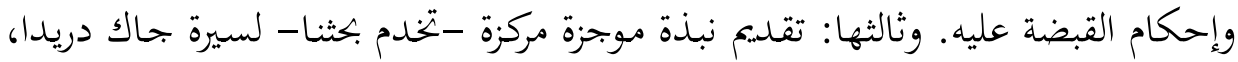

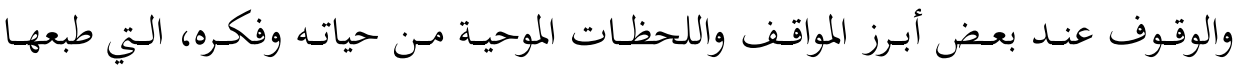

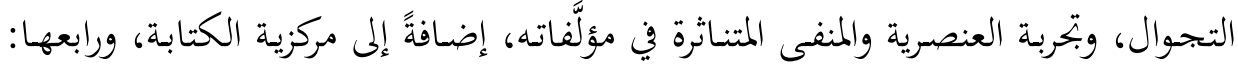

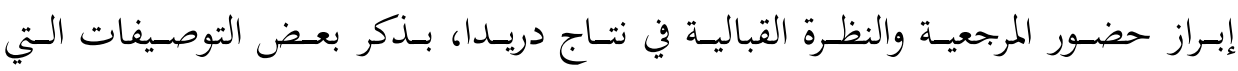

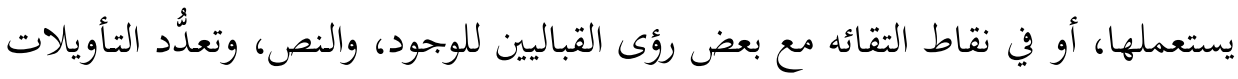
والمعاني (للنص).

وفي الأخير، يجب القول إن الهدف الأسمى من هذا البحث ليس بيان القول الفصل في

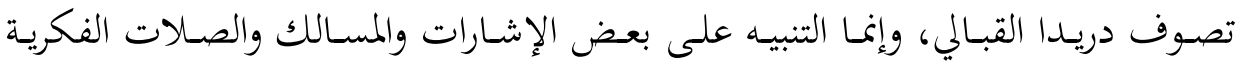

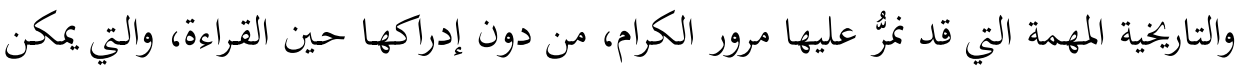

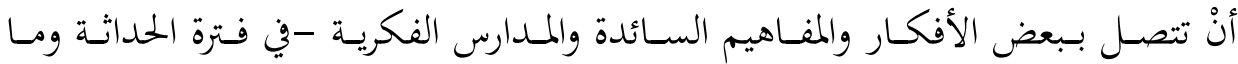

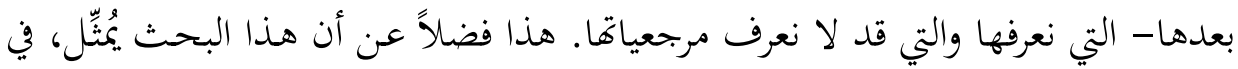

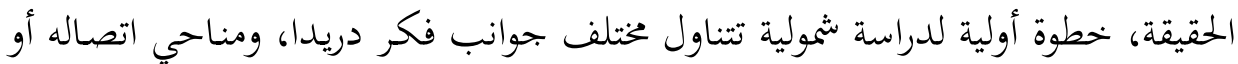

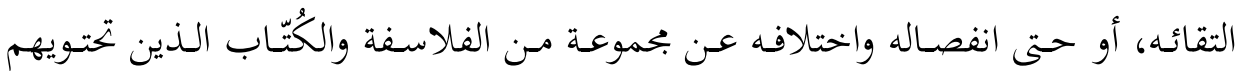
مؤلَّفاته الكثيرة.

ولعـل خـير مـنهج لاستقراء الأصـول اليهوديـة وتبياهـا في منهـاج دريـا هـو التفكيـك

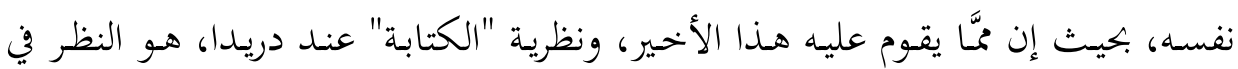

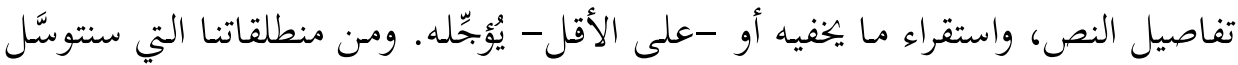

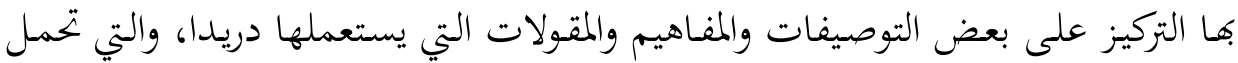
بُعْداً لاهوتياً للموروث اليهودين بعض التوصيفات

\section{أولاً: تمازجية العلاقة بين الأدب الفلسفي واللاهوت الديني}

يُعَدُُّ البحـثـ في موضـوع علاقـة الأدب (أو النظريـة الأدبيـة) بالدراسـات الدينيـة (أو

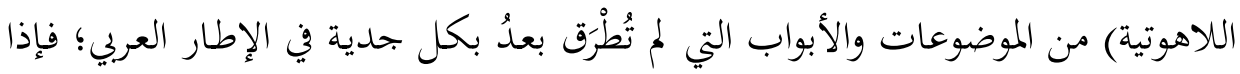




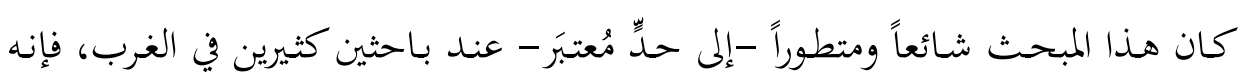

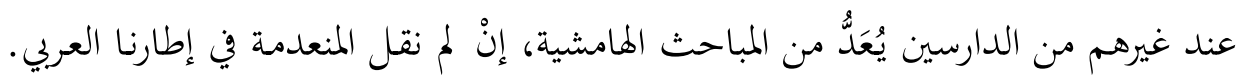

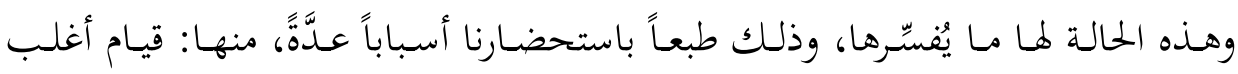

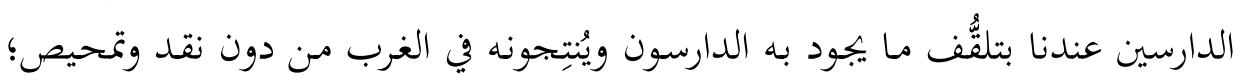

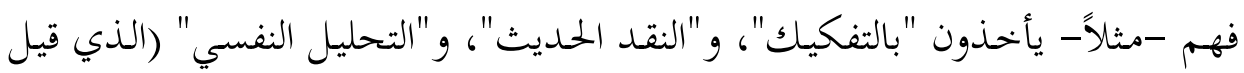

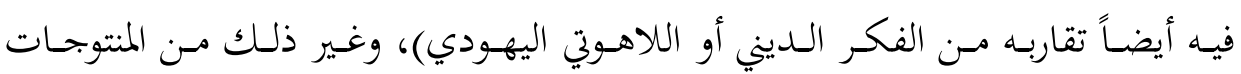

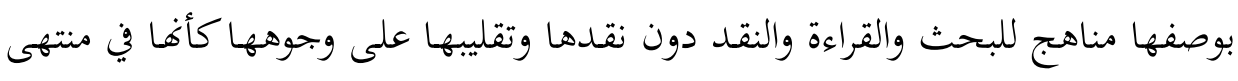
الكمال، بحيث لا يأتيها الباطل، وكذا دون معرفة أصولها ومُكوّناها وآلياتما ومقاصدها. ومن هذه الأسباب أيضاً: التقليد؛ فإفمم لا ينفكّون عن اجترار مفاهيم غيرهم، لأفم

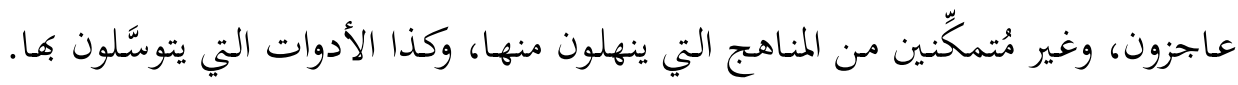

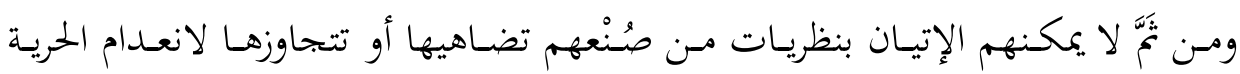

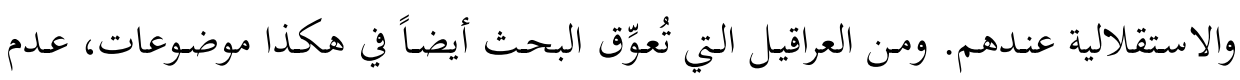

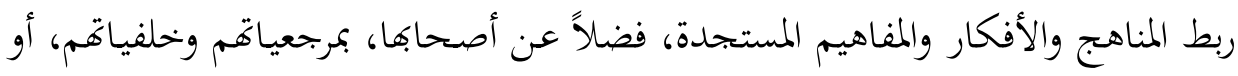

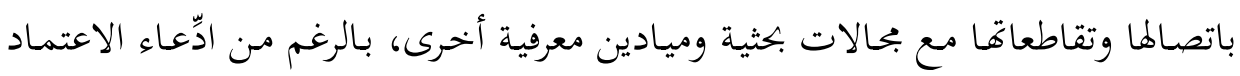
على حقول ومقاربات بحثية ومعرفية متقاطعة ومتداخلة. 10 فعلى المرء أنْ يتفحَّص ويتبيَّن -على أقل تقدير - ما يقرأه وينظر فيه.

وفيما يخص هذه العلاقة "المُغيَيَّة" التي تستحق التناول والدرس، يقول الكاتب والناقد

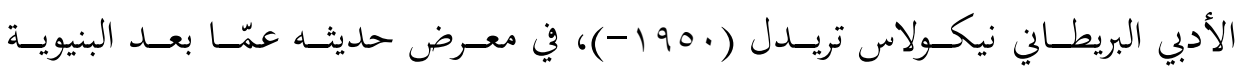

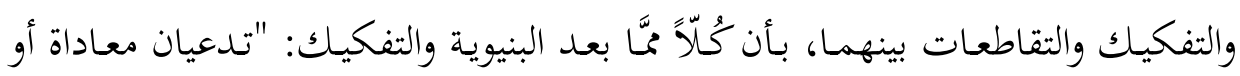

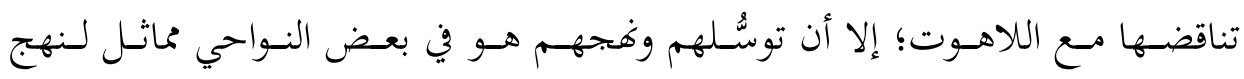

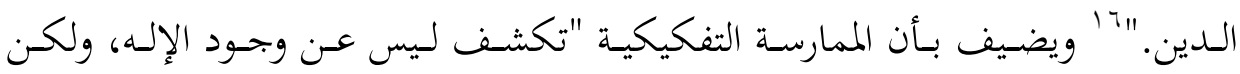

o' نشير هنا إلى المصطلح الإنحليزي الذي يفيد ذلك: "interdisciplinary approach". ${ }^{16}$ Tredell, Nicholas. "Euphoria (Ltd) The Limitations of Post-structuralism and Deconstruction" in: Issues in Contemporary Critical Theory, Ed. Peter Barry, 1987, p.94. 
غياب[هـ]، .. . مفهوم معقد للغياب؛ مثل اللعب المتواصل للاختلاف / الإرجاء؛ ولكن [عملية] القلب تظل ضمن التضاد (التعارض) اللاهوتي [...] إن الطور الأول والمهم في

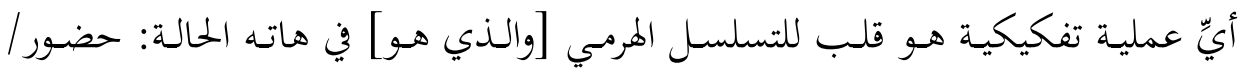
غياب." لا وعلى هذا، فالعلاقة ما بين المنهج التفكيكي واللاهوت تستحق التمحيص.

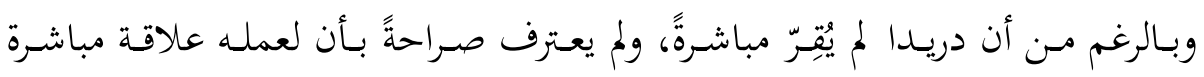

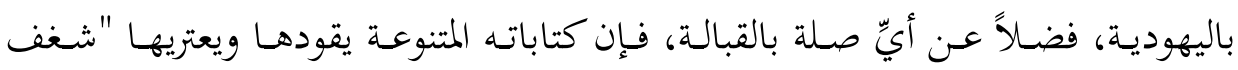
يهودي"؛ فالأكاديمي والفيلسوف واللاهوتي الأمريكي المعروف جون كابوتو (•ـ 1 (1-)

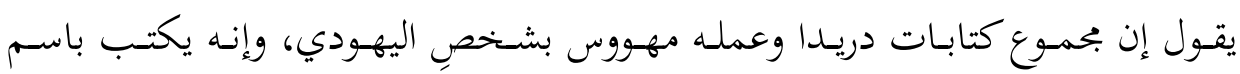

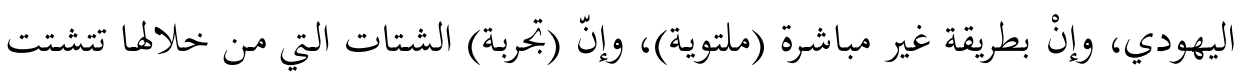

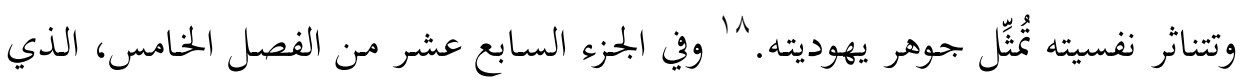

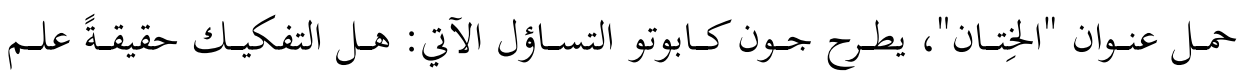
يهودي؟.

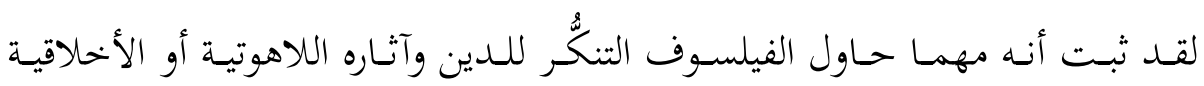
البعيدة، فإنه سرعان ما ينقشع وينكشف في تضاعيف قوله وفكره، مهما حاول إنكاره

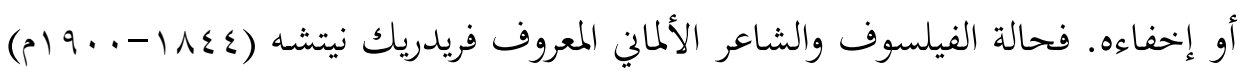

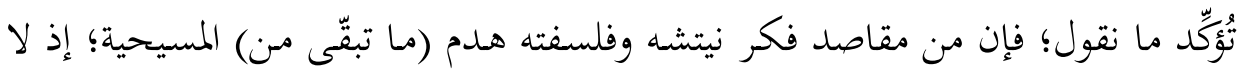
يخفى بأنه صاحب كتاب "عدوّ المسيح" The Anti-Christ، الذي حاول من خهن ملاله تقويض المسيحية، وشنَّ حرب عليها. وفي المقابل، ففي عمله ذائع الصيت "هكذا تكلم

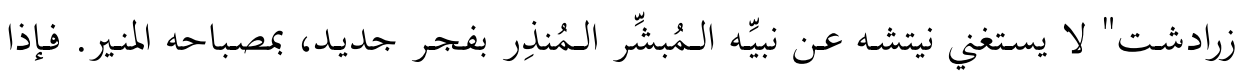

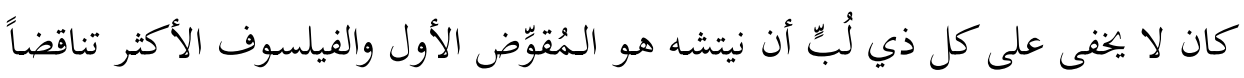

${ }^{17}$ Ibid. p. 94.

${ }^{18}$ Caputo, John. The Prayers and Tears of Jacques Derrida, Religion without Religion, United States: Indiana University Press, Bloomington and Indiana Polis, 1997, p. 203. (صلوات ودموع جاك دوبيدا، الدين بلا دين)

${ }^{19}$ Ibid., p. 263. 


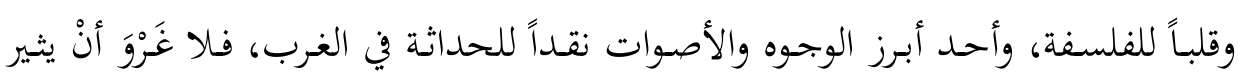
إعجاب دريدا منذ البدايات الأولى.

ومن جهة أخرى، ففي المقارنة البارزة التي يُقيقيمها الباحث الإنحليزي أيان ألموند، في

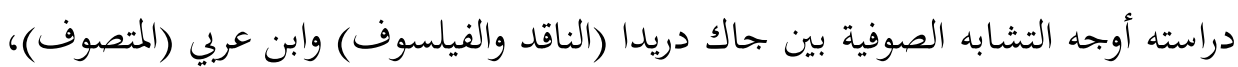

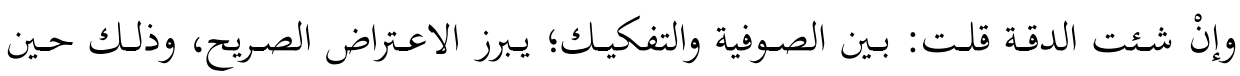

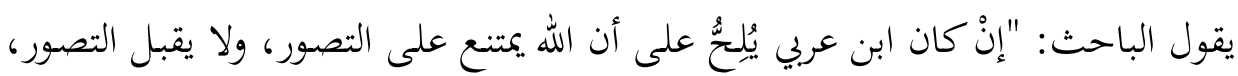

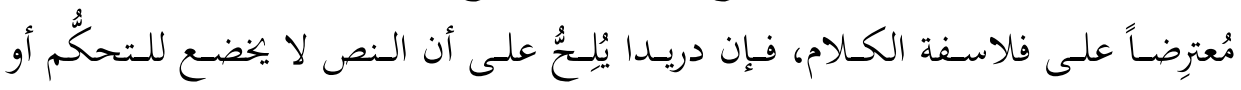

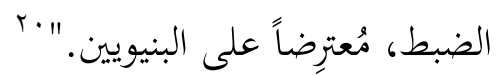

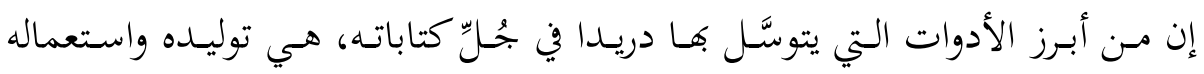

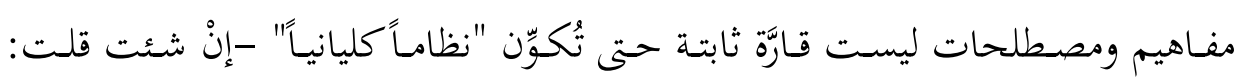

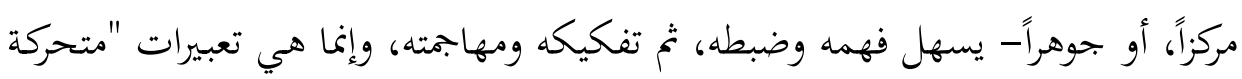

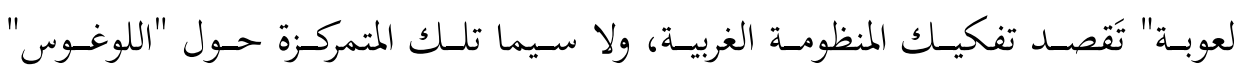

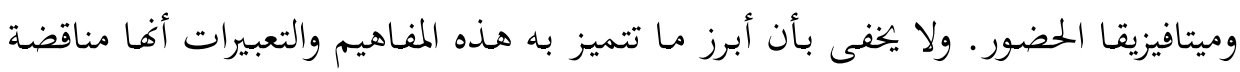

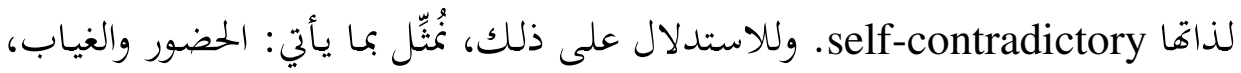

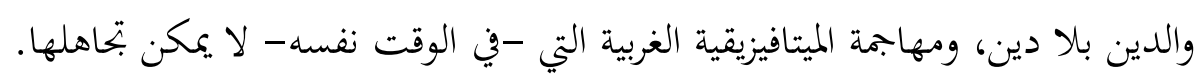
وفي مقدمتها المنهجية المُوضِّحة لطبيعة الصراع الفكري والديني الطويل بين اليهودية

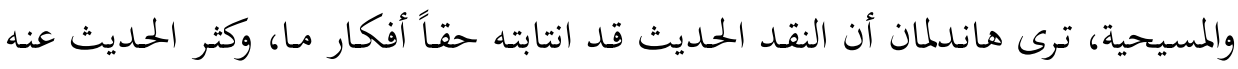

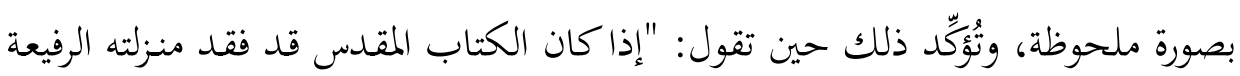

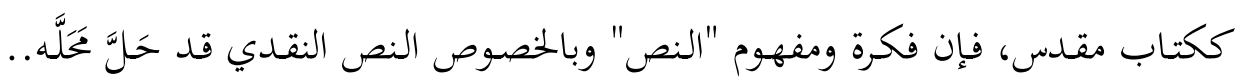

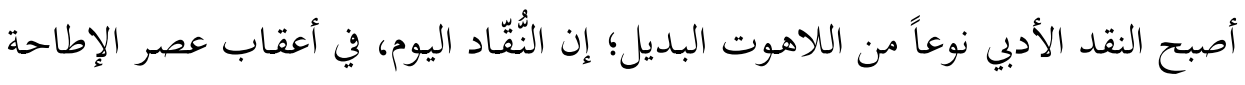

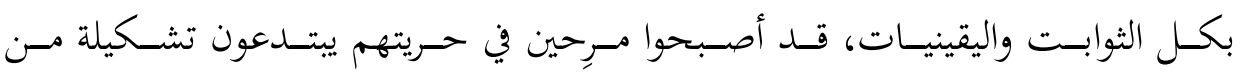

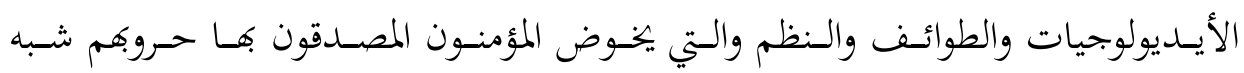




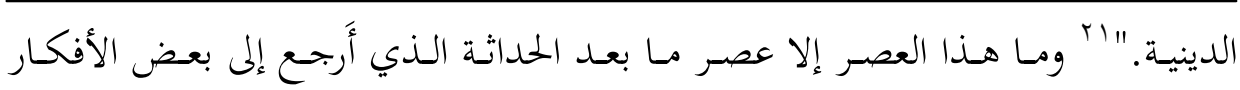

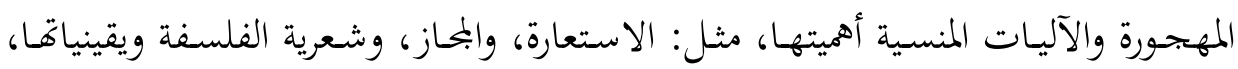

$$
\text { ومحدودية العقل ومراتبه. }
$$

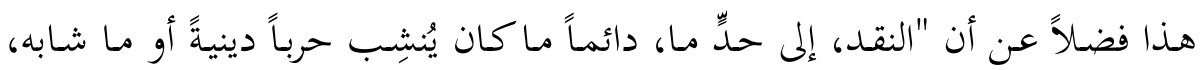

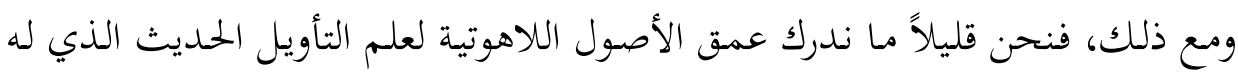

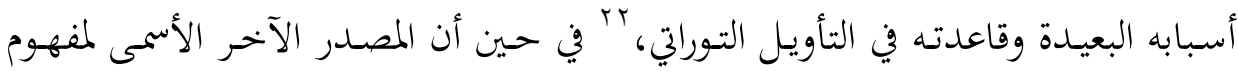

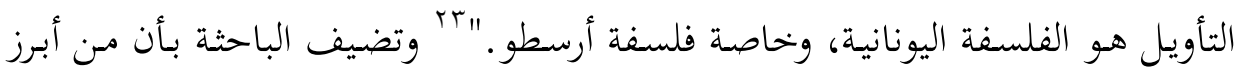

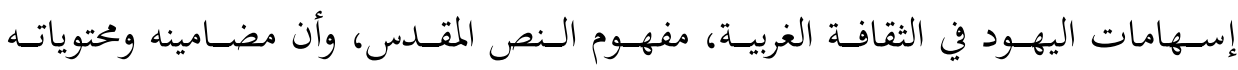

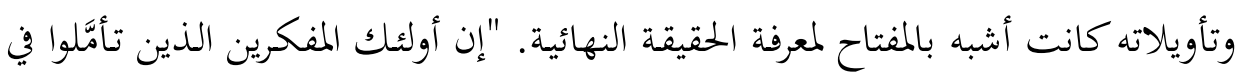

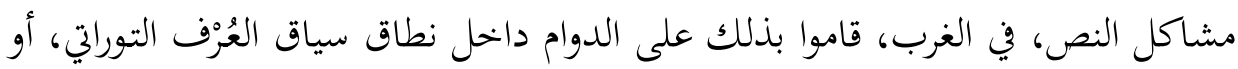

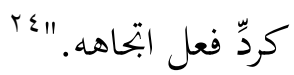

وحول الشقاق الذي طرأ بين اليهود والمسيحيين فيما يخص مسألة التأويل وتاريخه،

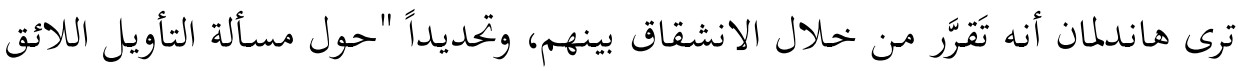

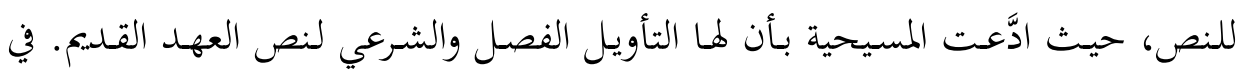

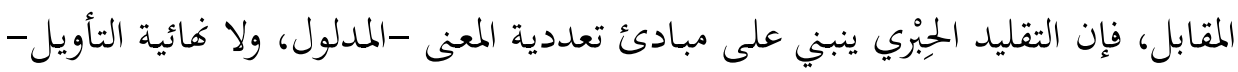

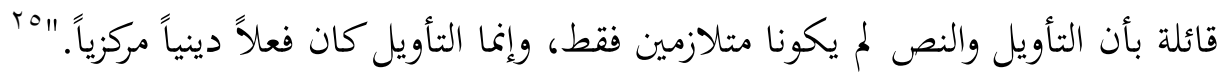

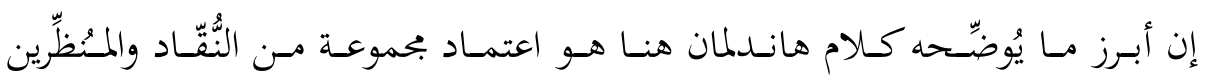

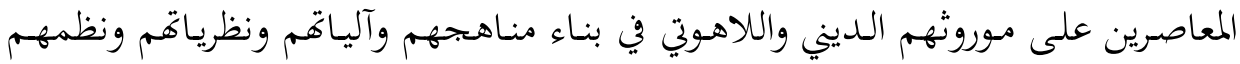

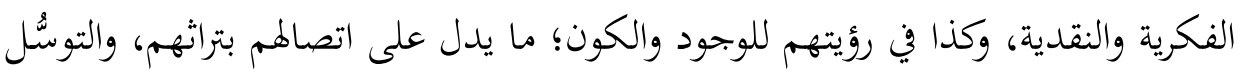
به، ومحاولة بعثه من جديد؛ سواء كان يهودياً، أو مسيحياً كاثوليكياً، أو بروتستانتياً.

${ }^{21}$ Handelman, The Slayers of Moses, xiii.

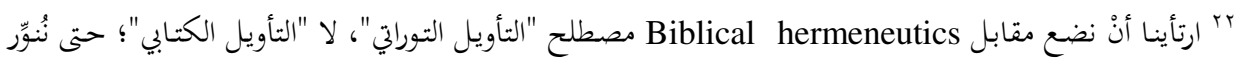

${ }^{23}$ Handelman, The Slayers of Moses, xiii.

${ }^{24}$ Ibid., xiv.

${ }^{25}$ Ibid., xiv. 
ثانياً: القبالة (تراثاً، ومفهوما)

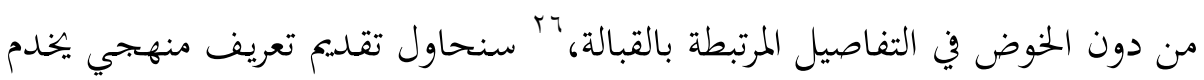

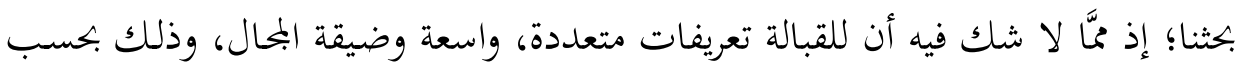

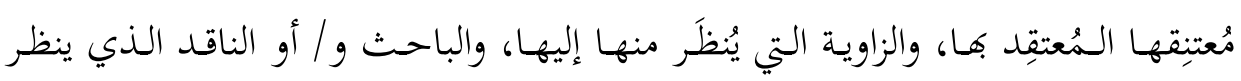

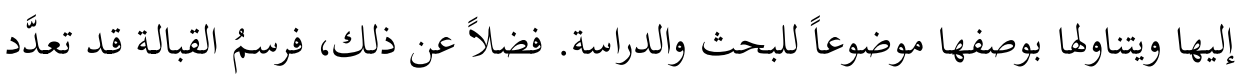

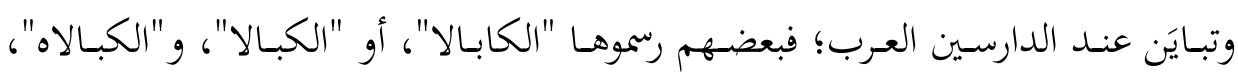

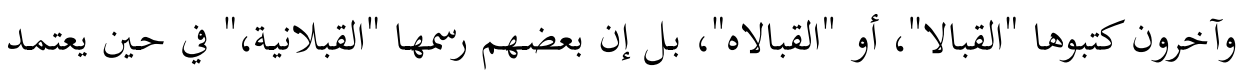

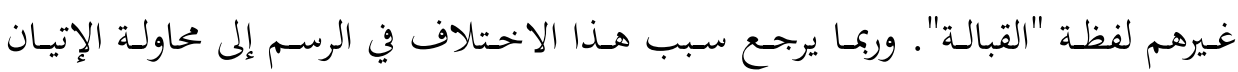

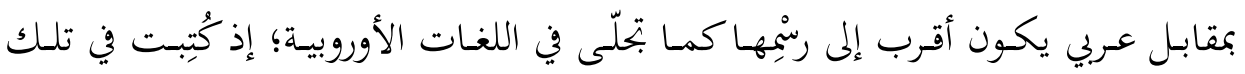

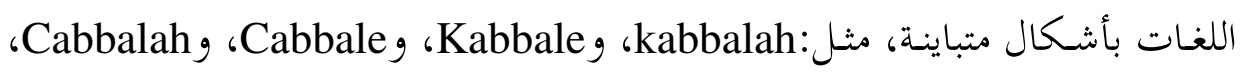

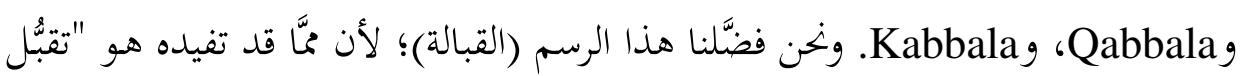

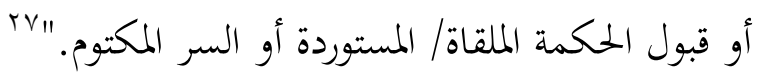

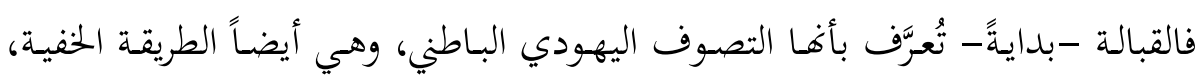

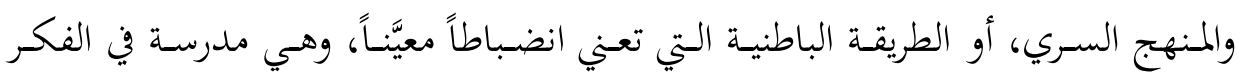

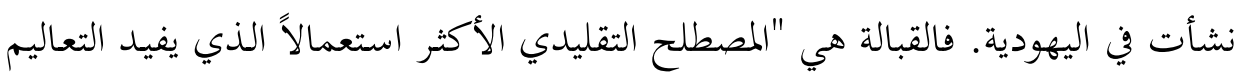

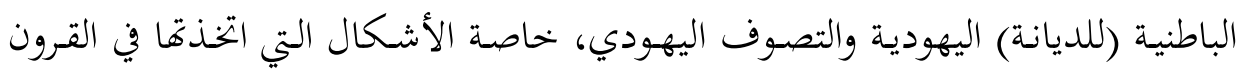

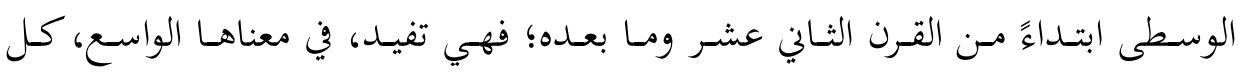

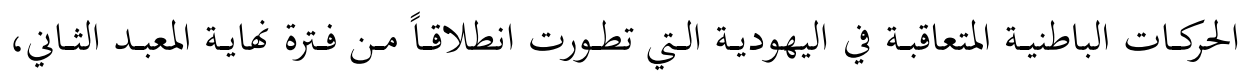

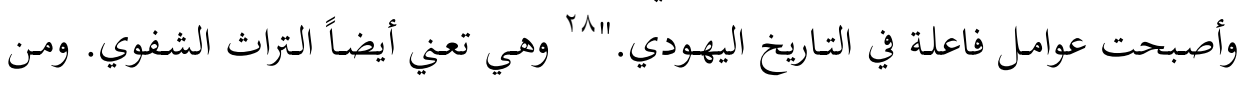

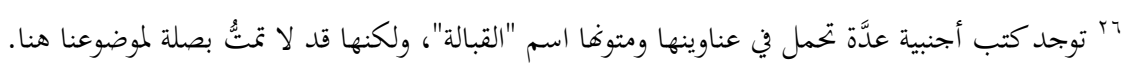

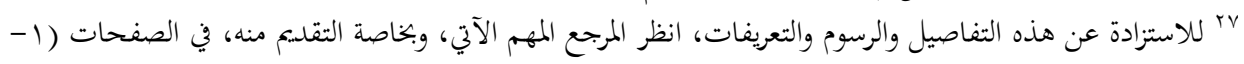

- The Kabbalah Unveiled. Translated into English from the Latin version by S. L. Mac Gregor Mathers. Third Impression, New York: The Theosophical Publishing Company, 1912. (في كثف الغطاء عن القبالة).

${ }^{28}$ Scholem, Gershom. Kabbalah, Israel: Keter Publishing House Jerusalem Ltd., 1974, p.3. (القبالة) 
تعريفاها الأخرى: "القبالاه"؛ وهي بحموعة التفسيرات والتأويلات الباطنية والصوفية عند

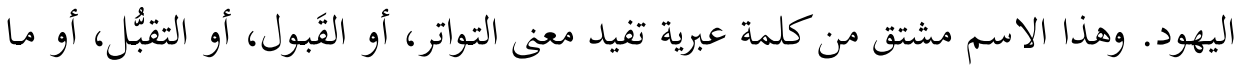

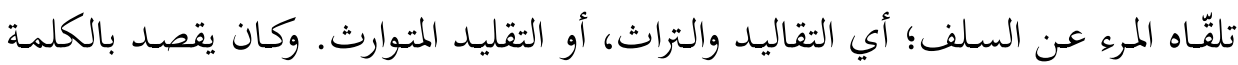

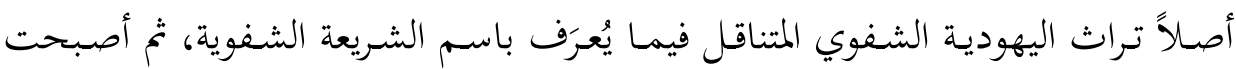

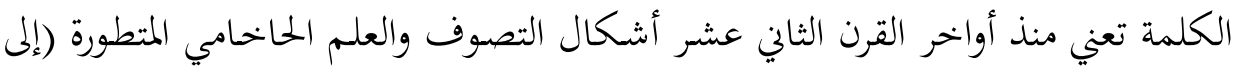

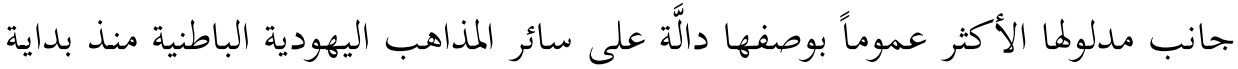

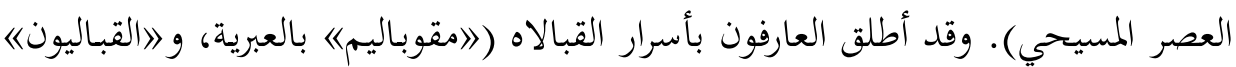

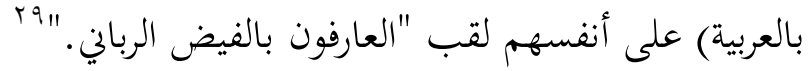

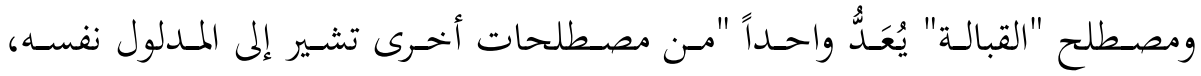

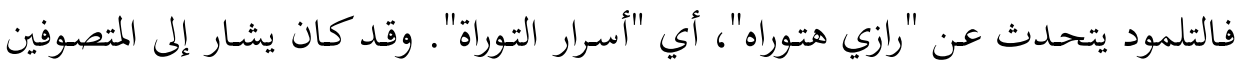

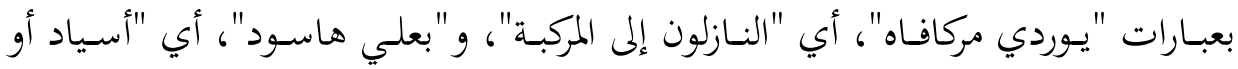

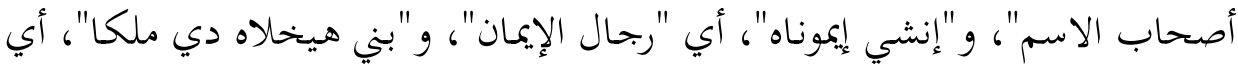

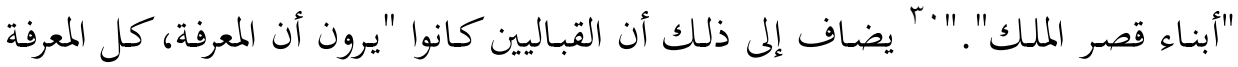

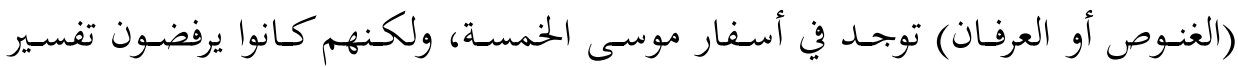

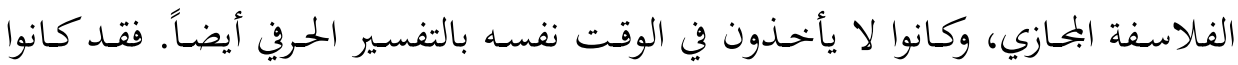

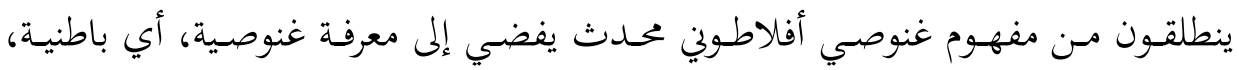

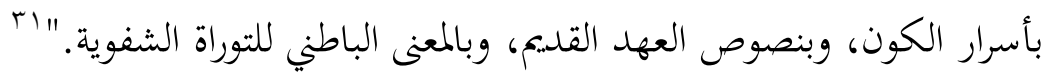

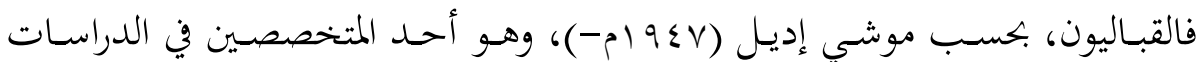

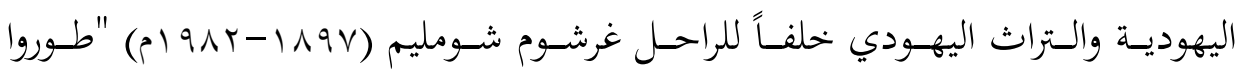

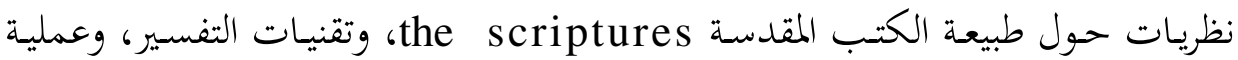

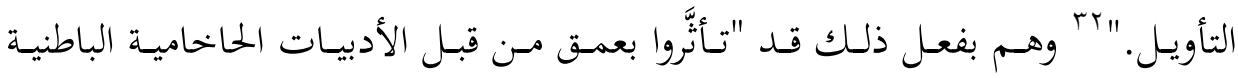
${ }^{29}$ http://islamport.com/d/1/aqd/1/321/1442.html من كتاب: موسوعة اليهود واليهودية والصهيونية لمؤلفه الراحل عبد الوهاب المسيري، وهي موجودة على الرابط أعلاه ألياً. " المرجع السابق.

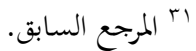

${ }^{32}$ Idel, Moshe. Absorbing Perfections: Kabbalah and Interpretation, New Haven and London: Yale University Press, 2002, p. xv. 


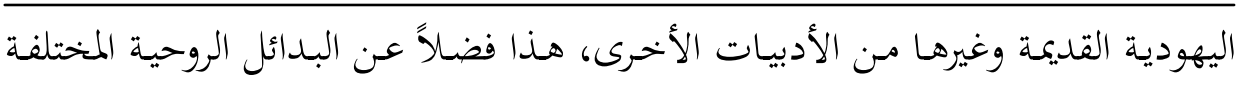

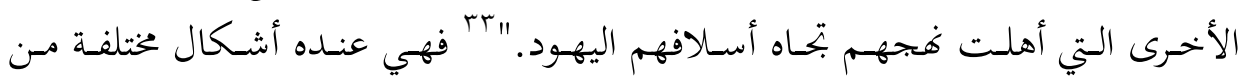
التفسيرية القبالية.

لقد تطورت القبالة بصورة كلية ضمن عالم الفكر اليهودي، وقد دأب القباليون على

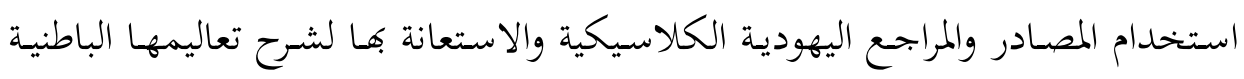

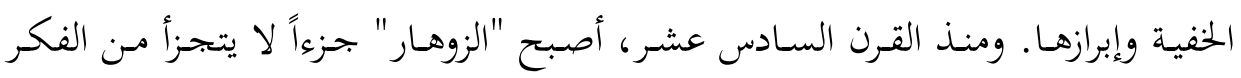

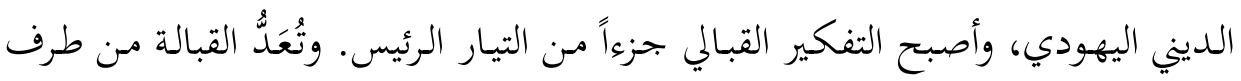

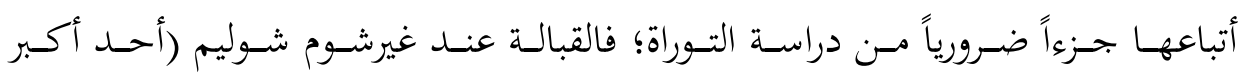
المتخصصين العارفين بها، الذي مثَّل سلطة مرجعية فيها في القرن العشرين) هي المصطلح

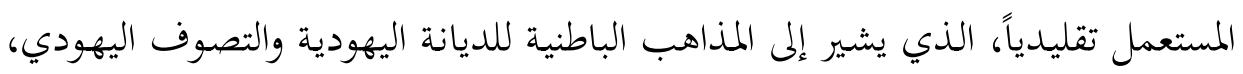

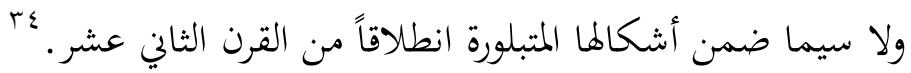
وبحسـب "الزوهـار"، أو سِفْر "الزوهـار" بالعبريـة (يفيـد "الإشـراق"، أو "الضياء"، وهـو

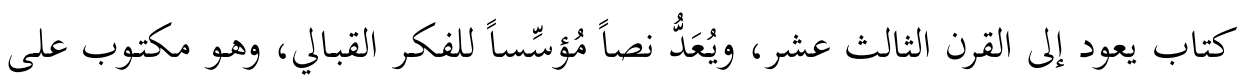
الأرجح بالآرامية، ولو أن بعض الدارسين يرجعون تلك التعاليم الصوفية الباطنية إلى القرن

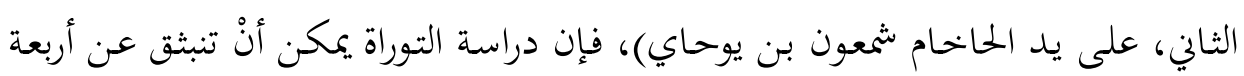

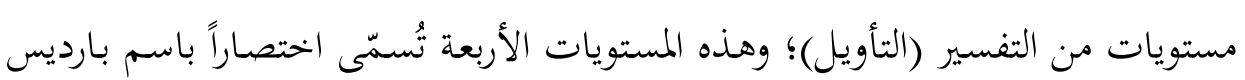
Pardes كالآتي:

- بيشات Peshat: تعني حرفياً بالعبرية "البسيط"؛ أي التفسيرات المباشرة للمعنى. - ريميـز Remez: تعـني حرفيـاً بالعبريـة "التلميحــات"، أو "الإشـارات"؛ أي المعـاني البمازية-الاستعارية (من خلال الإشارات الضمنية).

${ }^{33}$ Ibid xvi.

${ }^{34}$ Scholem, Gershom. La Kabbale, France Les Editions du Cerf, 1998, p. 43. 
- ديـراش Derash: تعـني حرفيـاً بالعبريــة "البحــثـ"، أو "الطلــب"؛ أي المعـاني الحاخامية- الحبرية التي تتمُّ عادةً من خحلال مقارنات تخيلية مع كلمات أو آيات شبيهة

- سـود Sod: تعـني حرفيـاً بالعبريـة "السـر"، أو "الغمـوض"؛ أي المعـاني الداخليـةالباطنية (الميتافيزيقية) المُعبَّ عنها في القبالة.

وغالباً مـا يذكر الدارسون في هذا المحال أسمـاء بعض المتصوفة اليهود الإسبان، أو مـا

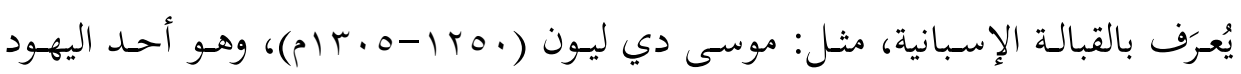

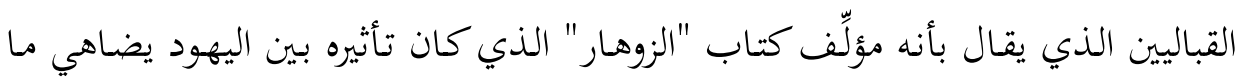

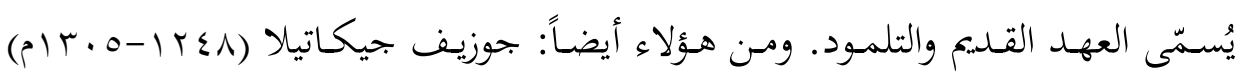

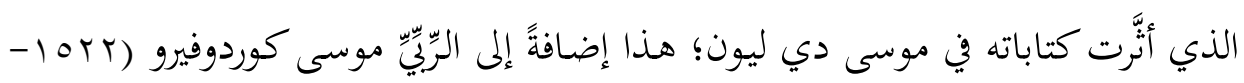

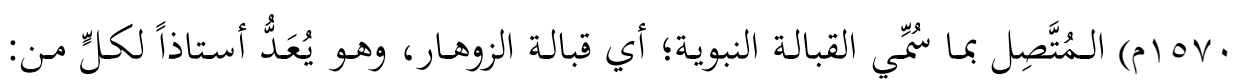

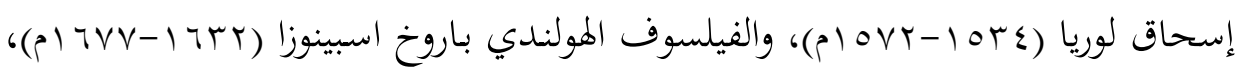
مب بمكن الرجوع إلى كتاب دريدا الآتي للوقوف على تداول هذه الكلمة في متن كتابه بحسب الصفحات المذكورة (ولو

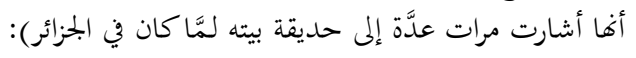

- Bennington, Geoffrey, and Jacques, Derrida. Jacques Derrida, Trans: Geoffrey Bennington, Chicago: The University of Chicago Press, 1993, pp.110-111, 237-238, 243-247, 312. (جاك وريدا)

- Wolfson, Eliot, "Assaulting the Border: Kabbalistic Traces in the Margins of Derrida," p. 478.

ويضيف الباحث عامر الحافي بأنه قد "ظهر بين اليهود الفرنسيين ابتحاهان فكريان كان لما أكبر الأثر في علم

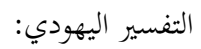
1- ابتحاه عقلي تأويلي يهتم بمقاصد الشريعة أكثر من الفروع الفقهية.

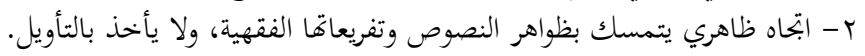

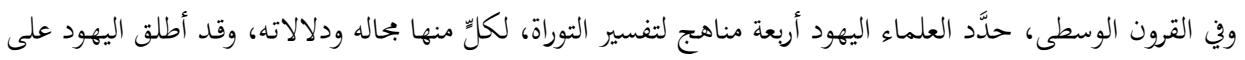

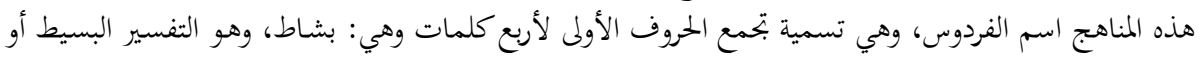

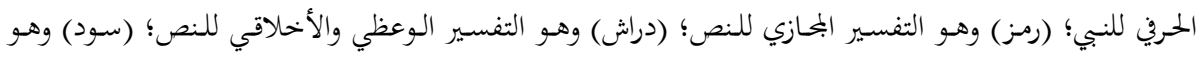

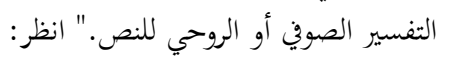

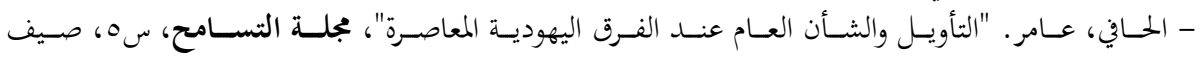

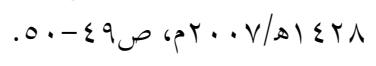




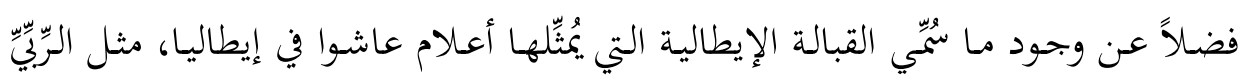

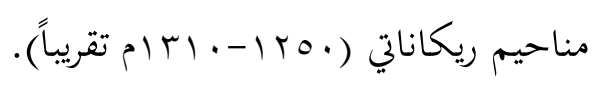

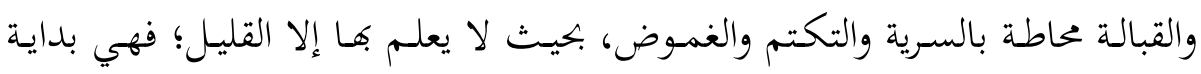

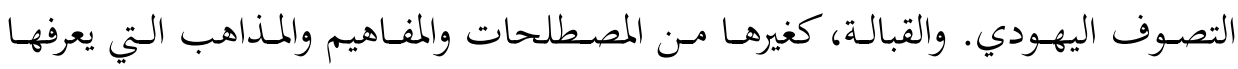

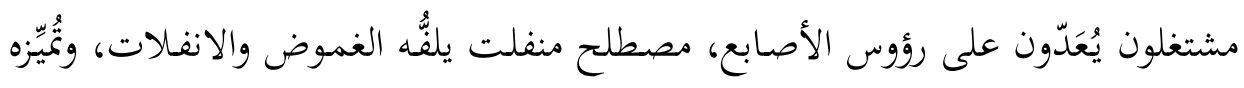

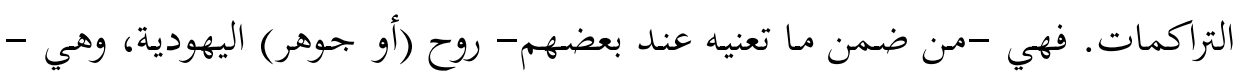

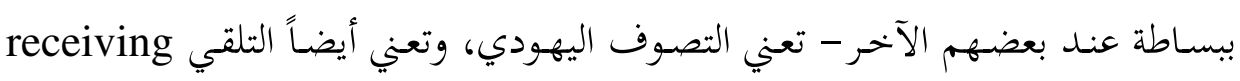

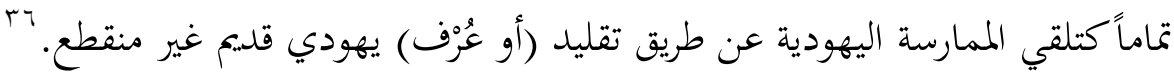
وتأسيساً على ذلك، فالقبالة the received wisdom هي: الحكمة المتلقاة،

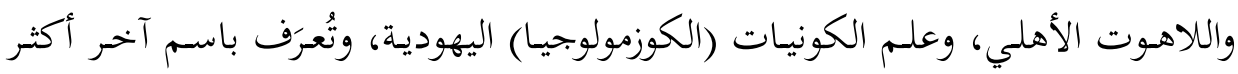

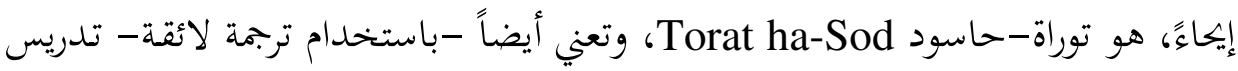

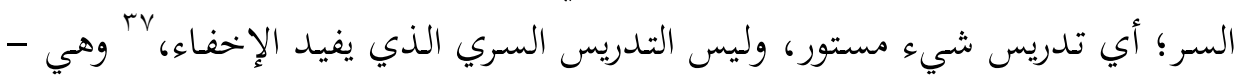

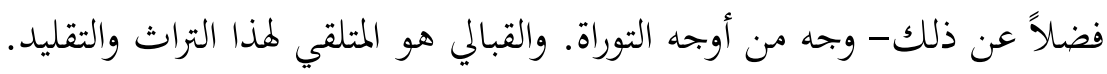

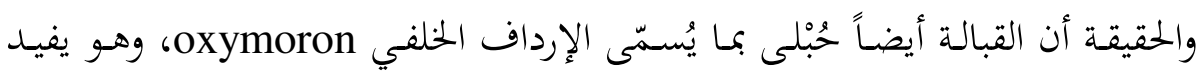

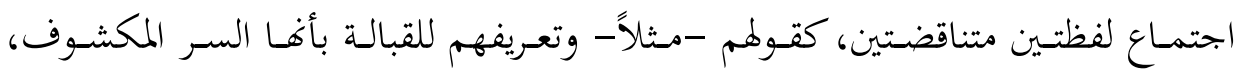

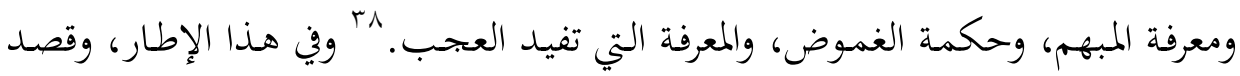

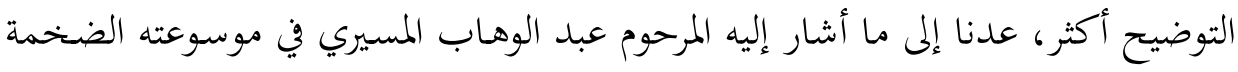

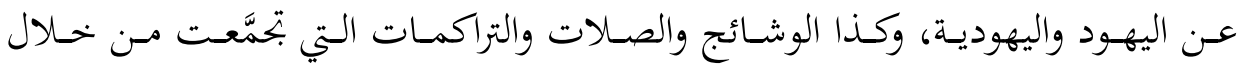

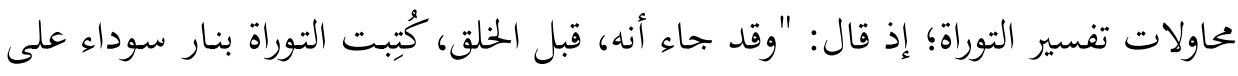

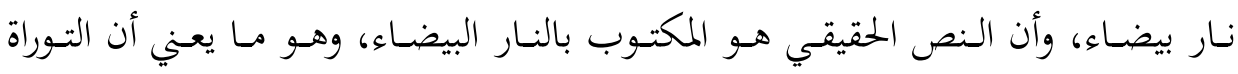

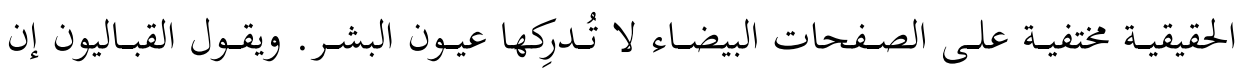

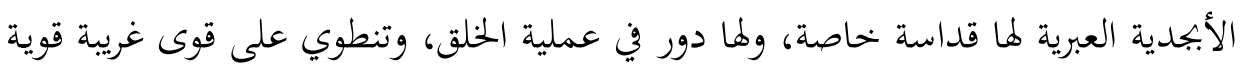

${ }^{36}$ Freeman, Tzvi. What Is Kabbalah? The Soul of Judaism, See the link below: - www.chabad.org/library/article_cdo/aid/1567567/jewish/Kabbalah.htm. ("ماهية القبايلة؟") 
ومعالٍ خفية، وبالذات الأحرف الأربعة التي تُكوّّن اسم يهوه (تتراجرماتون)، فلكل حرف

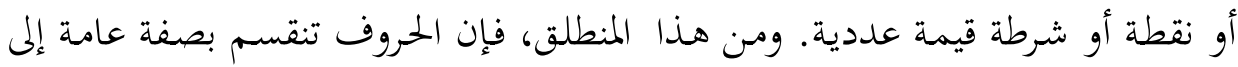

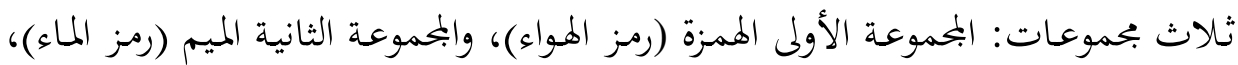

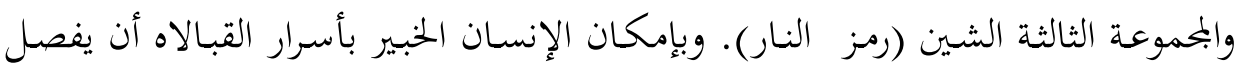

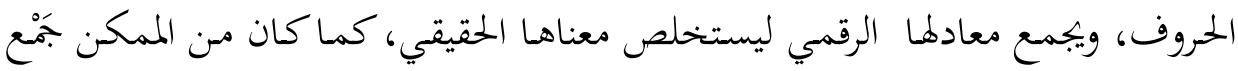

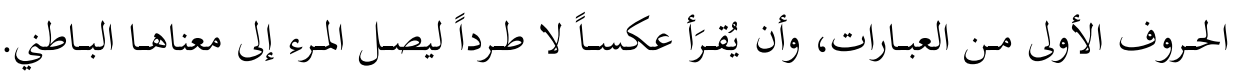

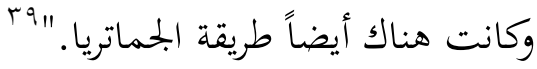

إن ما يفيدنا ويخدمنا، من هذا الاقتباس، هو التلميح إلى الفكرة التي يتقاسمها القباليون

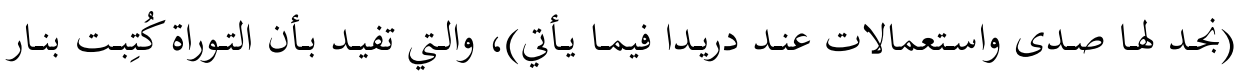

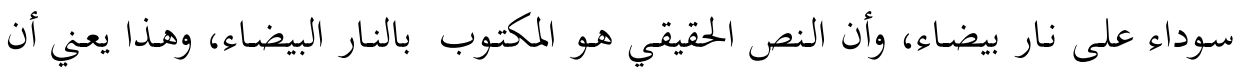

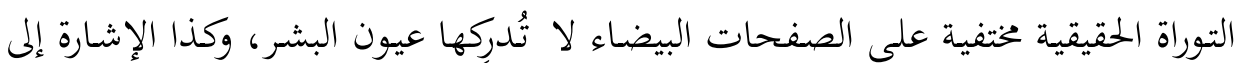
أهمية الأبجدية العبرية والحروف والرموز التي يستعملها دريدا في بعض المقاطع من كتاباته،

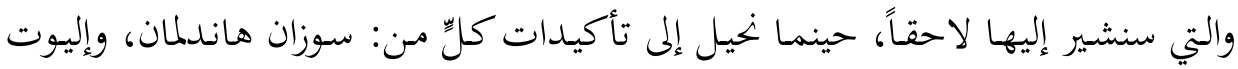
وولفسون اللذين تناولا التأثيرات والتقاطعات القبالية في فكر دريدا وأعماله.

ثالثاً: جاك دريدا؛ ثنائية المنفى والاغتراب، خصوصية النص والمعتقد من المعروف أنه عند ذكر اسم الفيلسوف الفرنسي جاك دريدا، فإنه يقترن بالتفكيك

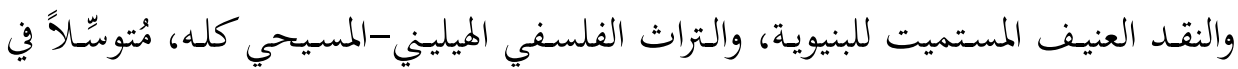

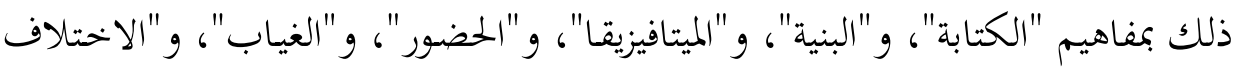

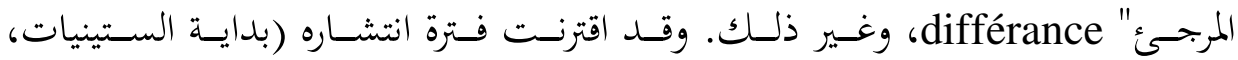
والتحولات العميقة التي عرفتها الساحة الفكرية والفنية في أوروبا، وبخاصة فرنسا وألمانيا)

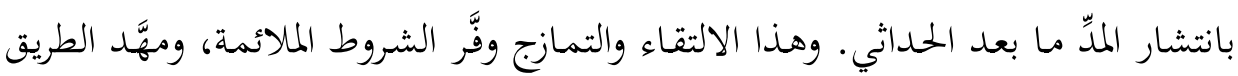

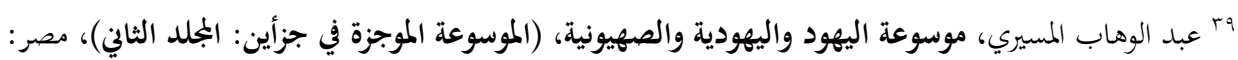

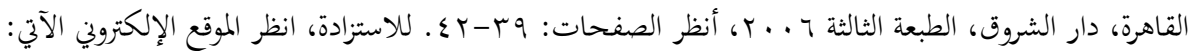
http://www.elmessiri.com/encyclopedia/JEWISH/ENCYCLOPID/MG5/GZ2/BA08/M D02/M0000.HTM. 
أمـام عـدَّة قراءات التمســت تقـويض المسـلَّمات واليقينيـات الفكريـة الكـبرى التي انبنـت عليهـا حضـارة القـول (أو اللوغـوس الفلسفي) . وبـرزت أيضـاً مـا بعـد البنيويـة، وظهـرت حركات تحررية تحريرية، مثل: دراسات الاستعمار، وما بعد الاستعمار، والحركات النسوية؛ فاشتعلت السـاحة، وانكوت بمصطلح "النقـد"، حتى صـار العصر عصر نقــ بامتيـاز. .ع ومن بين تلك الأمثلة والأفكار نذكر النقد المُوجَّه إلى الموية كوها ليست قارَّة ثابتة نقية، وإنما هي -دائماً- في إطار التكوُّن والتجلُّد.

وبحسب شهادة الكثيرين في الغرب كما في الشرق، فإن دريدا اء هو من أهم الفلاسفة الذين ظهروا في فرنسا بعد الحرب الأوروبية الثانية. ومن دون أدنى شكك، فبإن هذا الرجل يَسنعد أنه من بين أعظم الفلاسفة وأكثرهم إثارة للجدل في العقود القليلة الماضية، وذلك مـن خهالل مـا جـاء بـه مـن أفكار (مستجدةة) خخالفـة لما كانـت تعيشه السـاحة الفلسفية والفكرية في الغرب، أو من قراءاته الفريدة لأمهات النصوص الفلسفية والأعمال الأدبية،

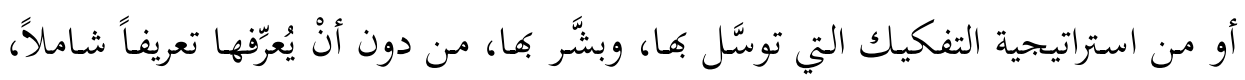
أو يمنحها مركزاً تعمل وَفْقه، وتلور من داخله. فهو لمُ يمنحها ذلك، وعياً منه، لأنه كان ينتقد المركز، وضمن مـا يعنيه هـا الأخهير هو مركزية اللوغوس اليوناني -المسيحي المرتكز

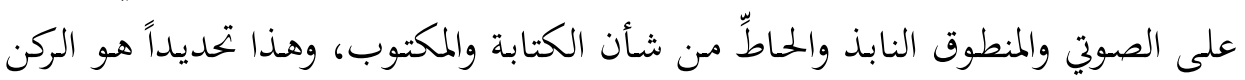

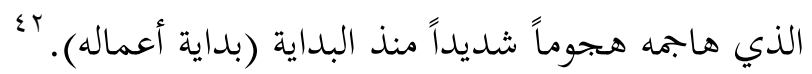

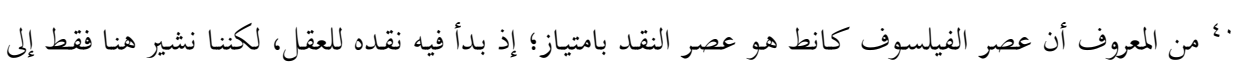

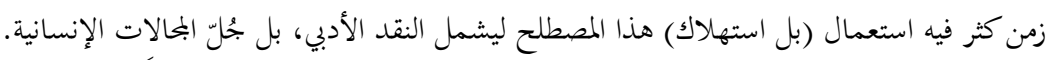

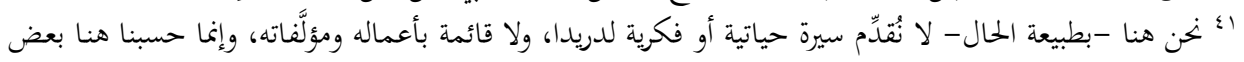

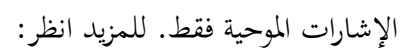

- Mikics, David. Who Was Jacques Derrida? An Intellectual Biography, New Haven and London: Yale University Press, 2009. (من يكون جاك دريدا؟ سيرة فكرية)

- Peeters, Benoît. Derrida: A Bibliography, trans: Andrew Brown, Cambridge: Polity Press, 2013. (دريدا، ببليوغرافيا)

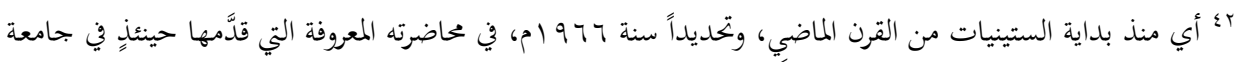

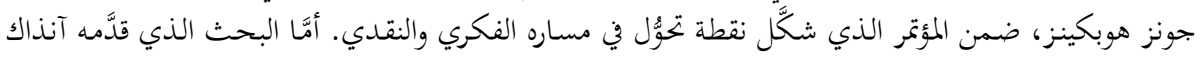

"La structure, le signe et le jeu dans le discours des sciences humaines". (البيضة واللعب (والعلامة في خطاب العلوم الإنسانية 


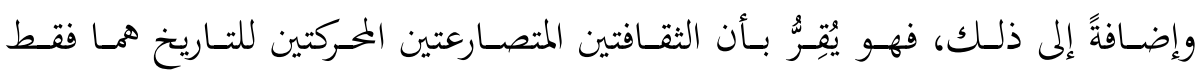

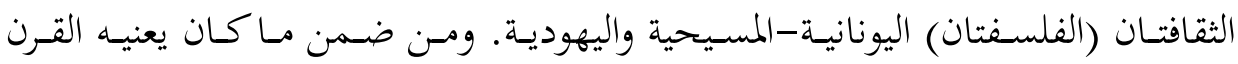

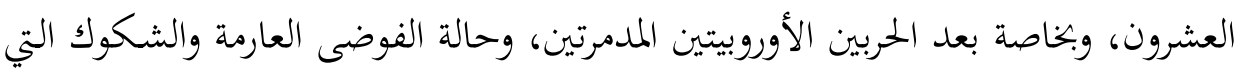

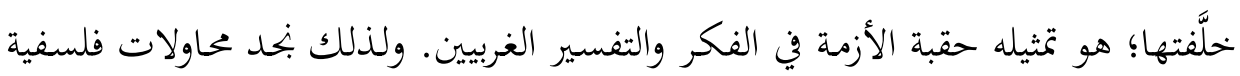

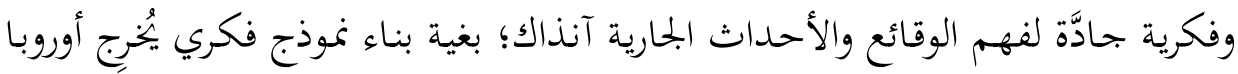

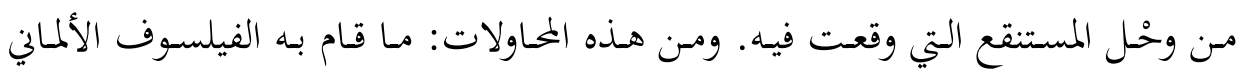
إدموند هوسرل (109 ا-14و ام)؛ إذ حاول بناء نموذج تفسيري (فينومينولوجي) جديد

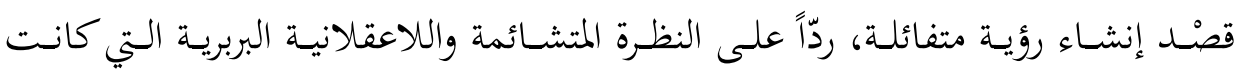

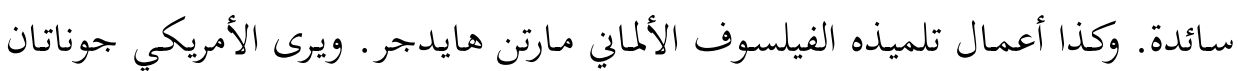

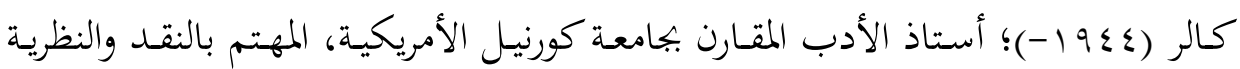
الأدبية والبنيوية -مثلاً- أن كتابات دريدا وقراءاته لبحموعة من النصوص تُوحي باستحالة بناء نظام نظري لائق متماسك شامل وسائد. باء ولئ والكل يعلم أن دريدا وُلِيد في مدينة البيار الجزائرية القريبة من العاصمة، وترعرع فيها،

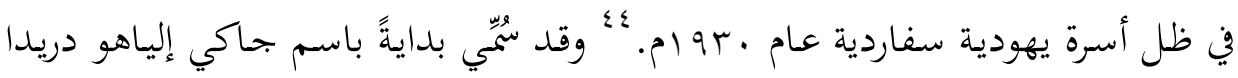
Jackie Elie Derrida

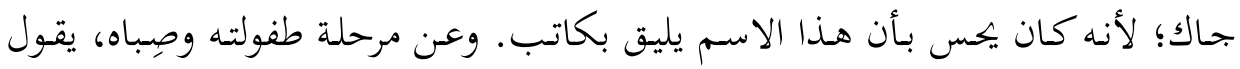

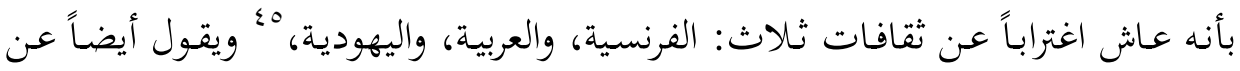

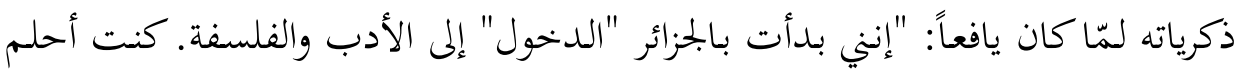
بالكتابة، وكانت هناك نماذج تصقل الحلم، ولغة ما وصور وأسماء تحكمه. إن الأمر شبيه

${ }^{43}$ Culler, Jonathan. "Jacques Derrida", Issues in Contemporary Critical Theory, Edited

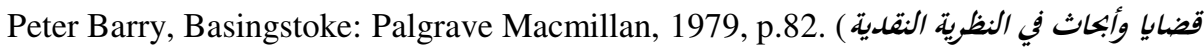
(المعاصة)

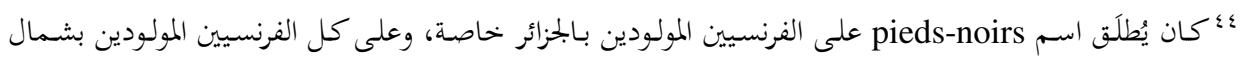

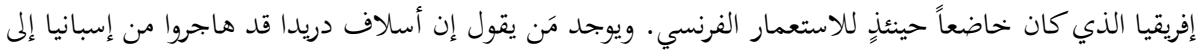

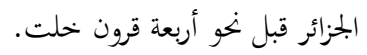

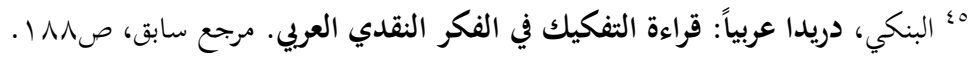


بالخِتان حقاً، فهو يبدأ قبلك. قرأت في وقت مبكر جداً: جيد، نيتشه، فاليري في الصف ألف

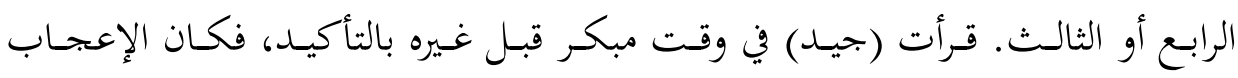

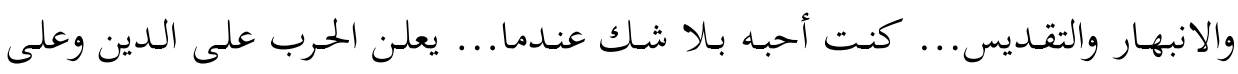

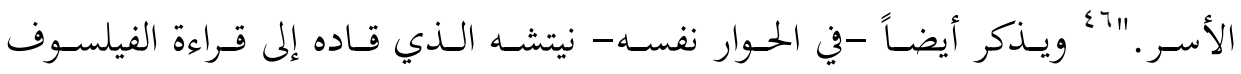

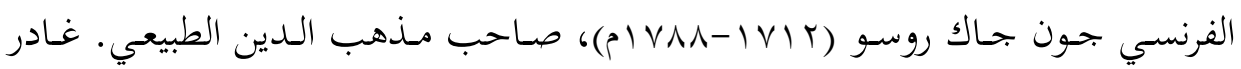

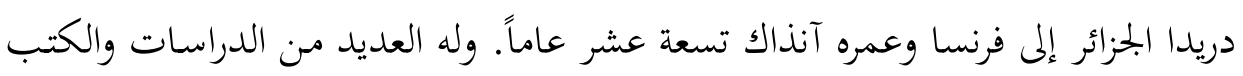
المهمة. غير أن من المفارقات التي وجب ذكرها الشهرة والترحيب الكبيرين اللذينِ لاقاهما

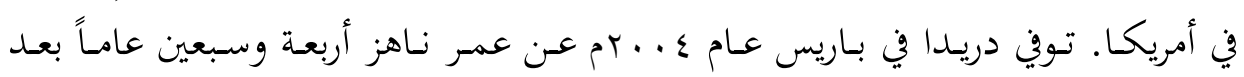
صراع مع سرطان البنكرياس.

\section{رابعاً: دريدا والقبالة؛ قراءة نقدية غيرية}

عالج بحموعة من النُّنّاد والدارسين الغربيين حضور القبالة في فكر دريدا، ومن هؤلاء:

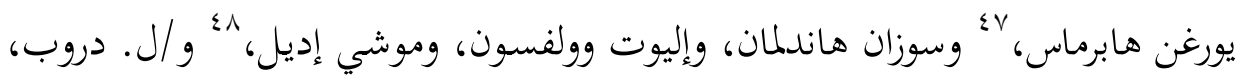

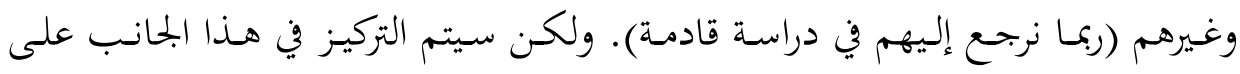

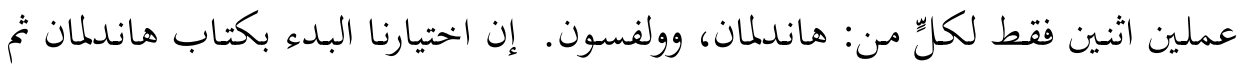

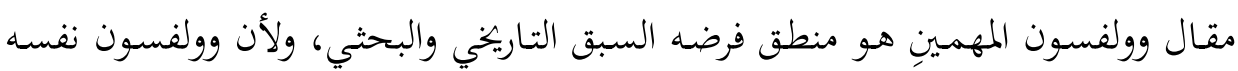

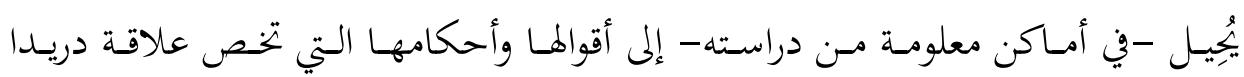
بالتصوف اليهودي والتفكيك.

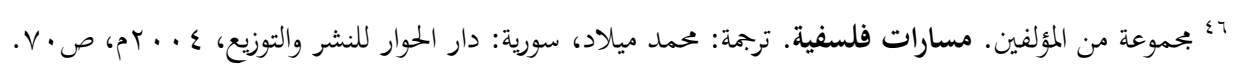

${ }^{47}$ Habermas, Jürgen. The Philosophical Discourse of Modernity, Twelve Lectures,

Trans: Frederick Lawrence, Massachusetts: Massachusetts Institute Technology, 1987, pp. 161-184.

انظر بخاصة الفصل السابع من الكتاب: يورغن هبرماس، القول الفلسفي للحداثة، ترجمة: فاطمة الجيوشي، دمشق:

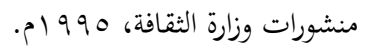

48 Idel, Moshe. Absorbing Perfection: Kabbalah and Interpretation, New Haven and London: Yale University Press, 2002. See also:

- Idel, Moshe. Kabbalah: New Perspectives, New Haven: Yale University Press, 1988. 
ا ـ قراءة في كتاب سوزان هاندلمان (قتلة موسى: انبثاق التفسير الحاخامي في

النظرية الأدبية الحديثة): 9 ؛ أن

\section{أ. تعريف بالباحثة وأهمية الكتاب:}

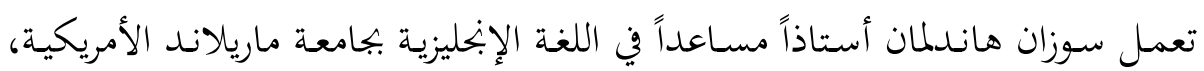

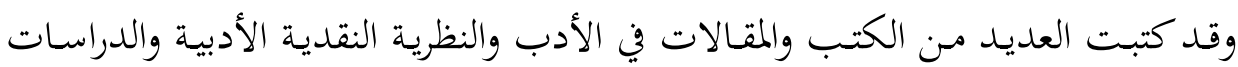

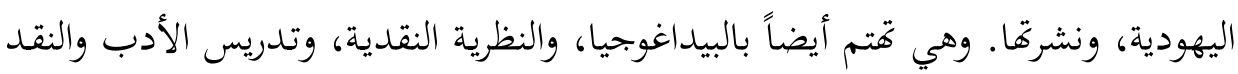
الأدبي والفكر اليهودي، وغير ذلك من الاهتمامات.

في هذا الكتاب (قتلكة موسى)، تفحص هاندلمان الأصول اللاهوتية وتدرسها، حتى

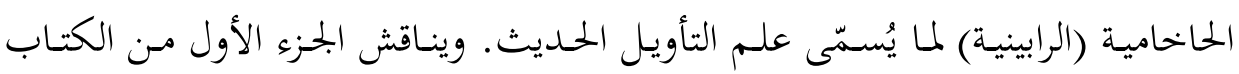

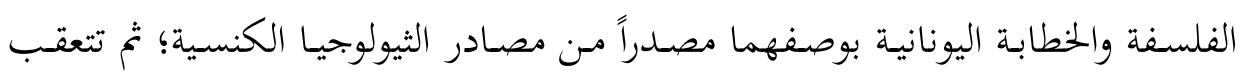

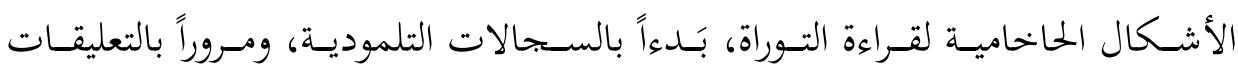

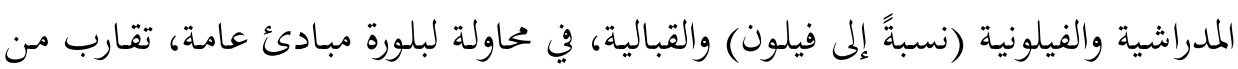

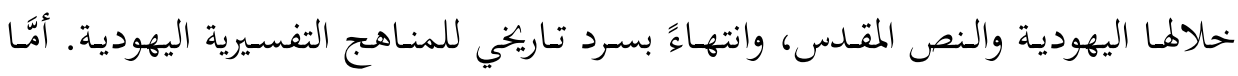

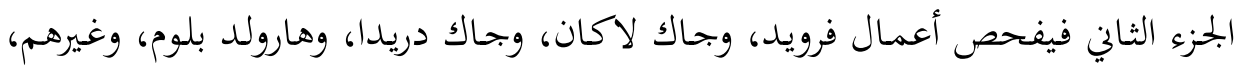

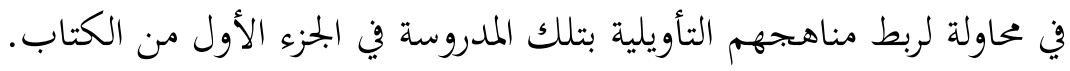

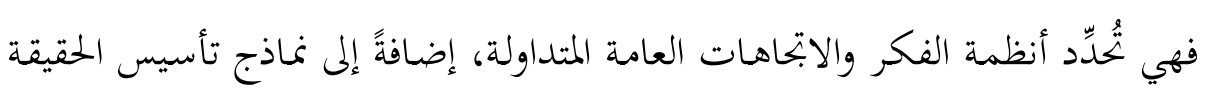

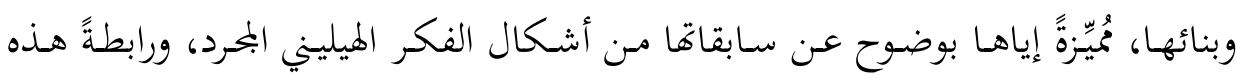

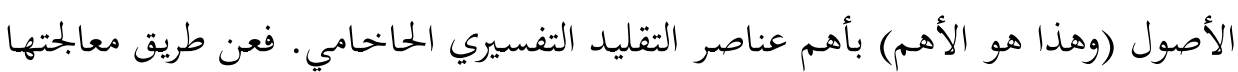

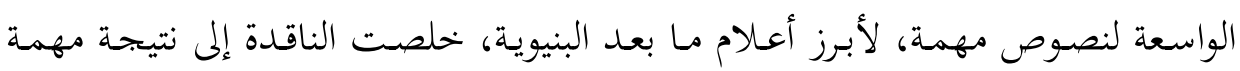

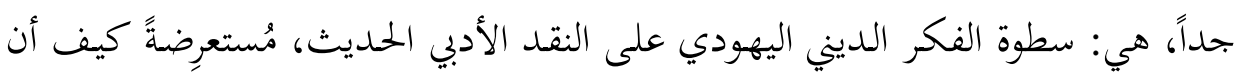

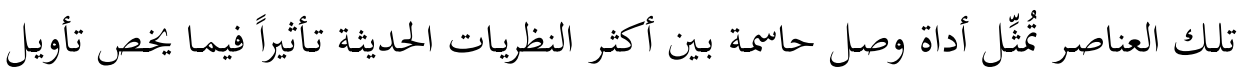

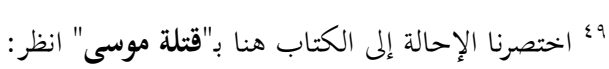
The Slayers of Moses: The Emergence of Rabbinic Interpretation in Modern Literary Theory, 1982 . 
النصوص، وذلك من سيغموند فرويد (مع التحليل النفسي)، إلى كلٍٍ مـن: جاك لاكان،

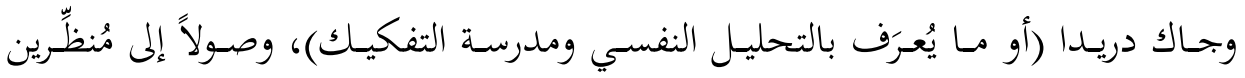
أدبيـين حـاليين (مثل: هارولـد بلوم، وجـوفري هارتحان) يجيون التفسير الحاخـامي. وفيمـا يخص حالة هارولد بلوم، فيان نفوذ القبالة بـارز جلي في نتاجهه على نحوٍ أكثر منه عند دريدا، كما تُؤكِّد الباحثة في متن الكتاب. ويمكن للباحثث المهتم أن يعود إلى كتاب بلوم

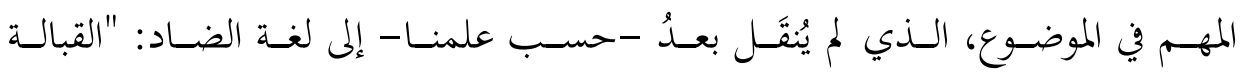
والنقد".

ففـي بدايـة الثمانينيـات، عنــدما كانـت هانــلملان تكتـب عـن التحـولات الكبـيرة في مستجدات النقد الأدبي والنظريات المحدثة في الغرب، اكتشفت الآثار والارتباطات القوية لهـه الأخهيرة بالأبعاد الدينيـة اللالهوتيـة الرابينيـة-الحاخحاميـة الصـاعلة بالخصوص والمحاربـة للتعـاليم والتقاليـد الميلينيـة-المسـيحية. ومسن أبرز الوجـوه والنّّبّاد الذين أتـت على ذكرهم الباحثة: هارولد بلوم، وسيغموند فرويد، وجاك لاكان، وجاك دريدا. وتشير في مقدمتها المنهجية إلى أنه ظهر حديثاً (أي مـا بعد النصف الثاني مـن القرن العشرين) بحموعة مـن المعترضين المتحدين للتفسير المبني على التعليم والتقليد اليوناني -المسيحي، أبرزهم: فرويد، ولاكـان، ودريـدا الذذين بجـاوزوا المشهـد النقـدي الأدبي المعاصـر، قـالبين رأسـاً على عقـب المفاهيم الكالسيكية المتعلقة بالمعنى والتأويل والتفسير. ولكن حتماً يبقى من أبرزهم دريدا، ذلك الـُّجادِل العنيف بخطابه النقدي الساخر المستمر اللاذذع بجـاه التقليـد الأنطو -ثيولوجي للفلسفة الغربيـة، مُلتمِسـاً مـن وراء ذلك Écriture- تعطيل التقليد اليوناني -المسيحي في الفكر واستبدال مفهومه عن الكتابة 01 ب. Writing

${ }^{50}$ Bloom, Harold. Kabbalah and Criticism, Seabury Press, 1975.

${ }^{51}$ Handelman, The Slayers of Moses, xiv.

تُفضِّل هاندلمان وضع لفظ "النص" Scripture مقابل Écriture. 


\section{ب. دريدا: الكتابة، والكتاب (النص):}

إن مـا حاولت هاندلمان تأكيده بوصفه شيئاً فريداً عن الفكر الرابيني هو هربـه (أو

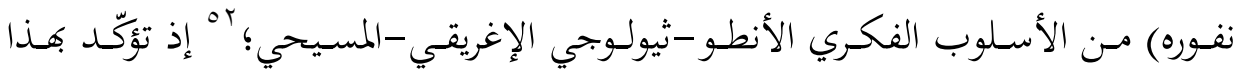

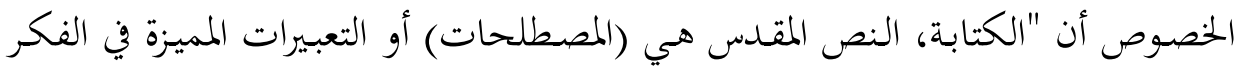

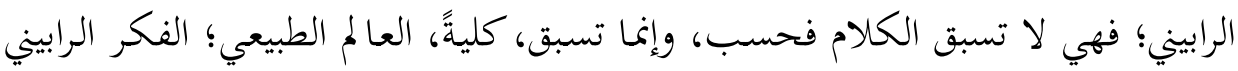

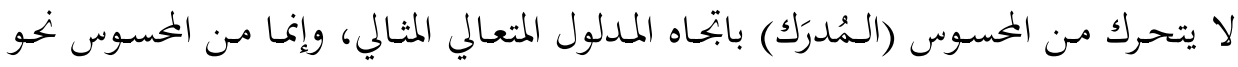

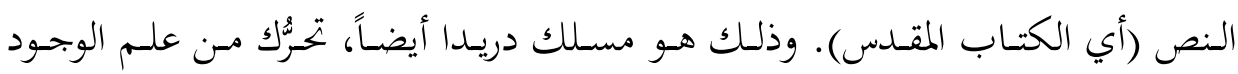
Ontology

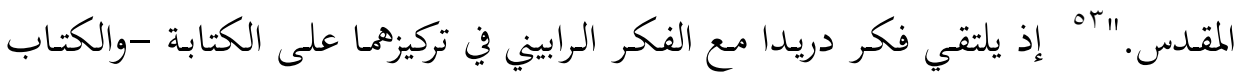

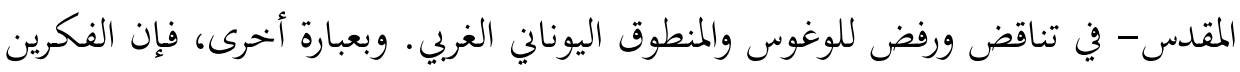

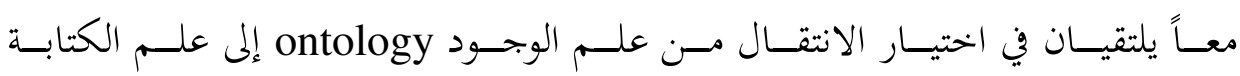
grammatology

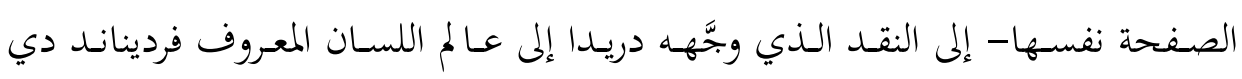

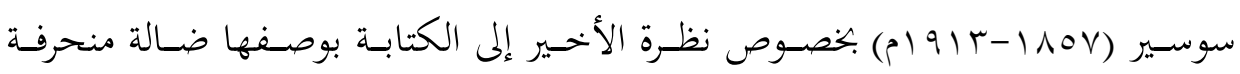
فاسقة.

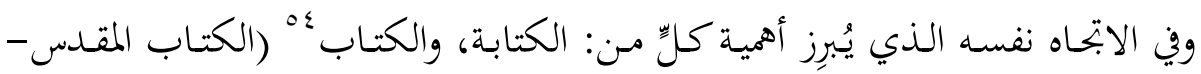

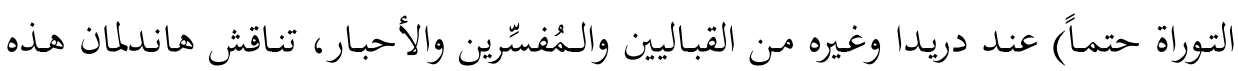

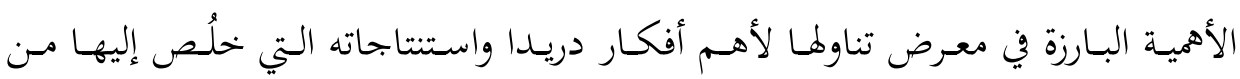

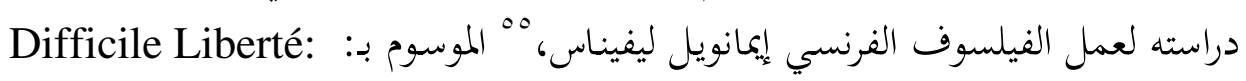
.Essai sur le Judaisme

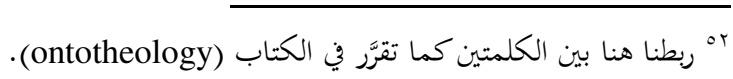

${ }^{53}$ Handelman, The Slayers of Moses, p.168.

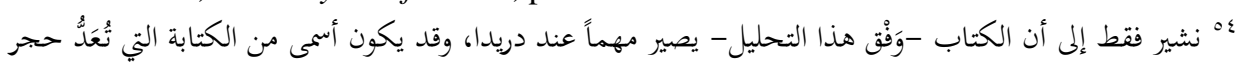

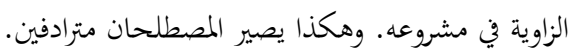

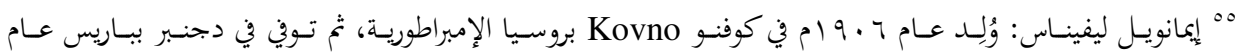

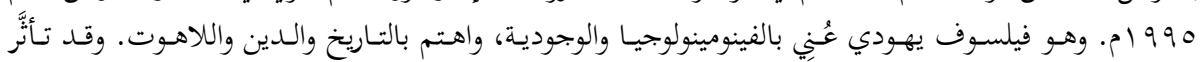

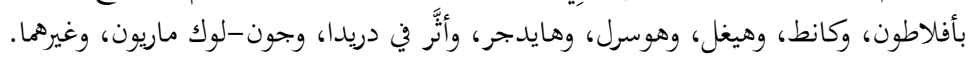




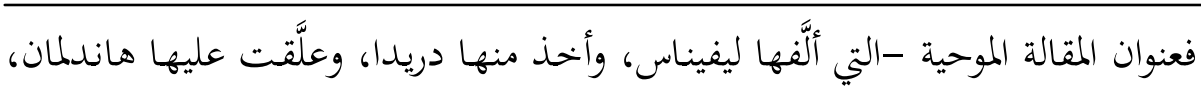

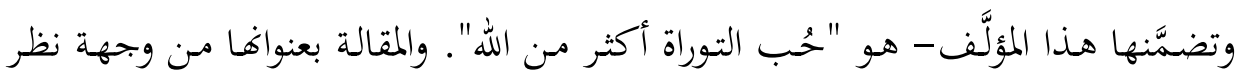

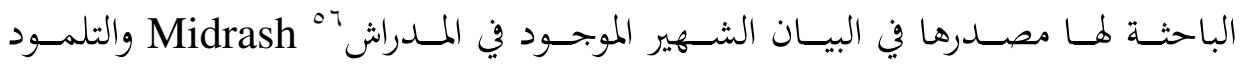
Talmud

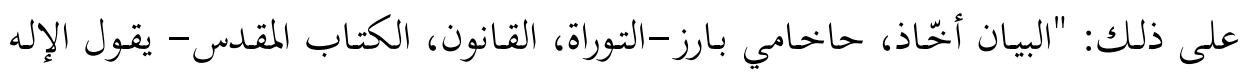
بأها أبلغ أهمية منه. "Vه" ثم تشير مباشرةً إلى أن فرويد ودريدا والممارسين الآخرين للهرطقة

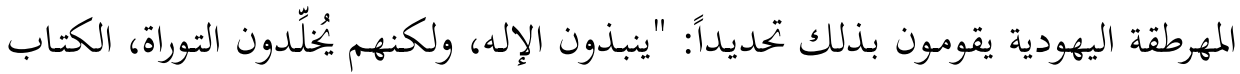

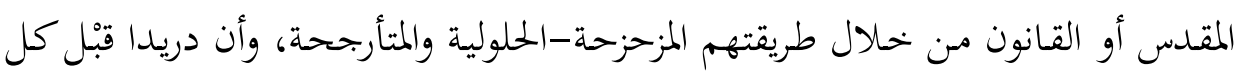

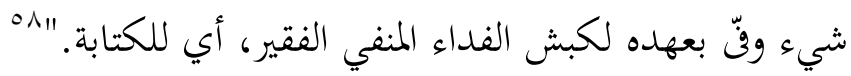
وعلى هذا، وفي شكل يتناسق والفكر القبالي، فإن الكتابة عند دريدا محبوبة أكثر من

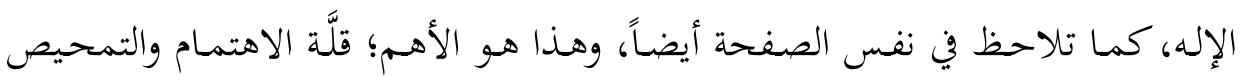

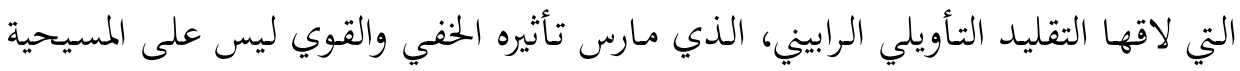

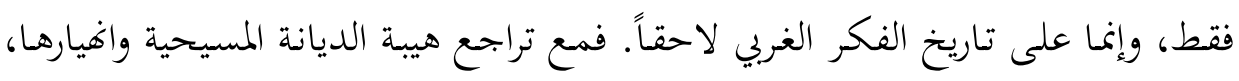

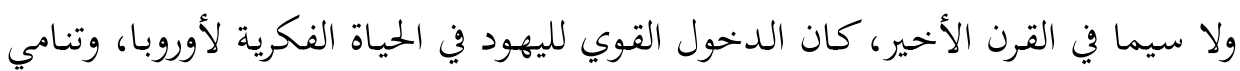

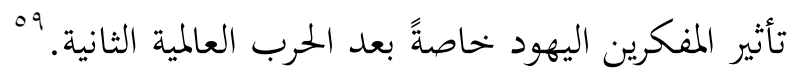
وفيمـا يخص عمل دريـا الفريـد، فبإن هانـلمان ترى أنه "يُعَدُّ الأخهير ضـمن سلسـلة

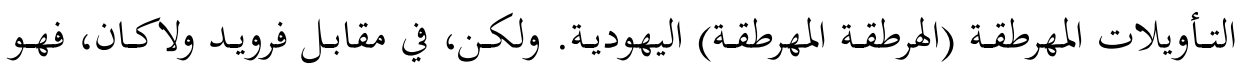

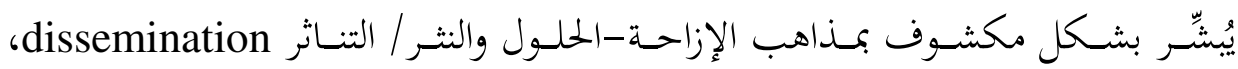

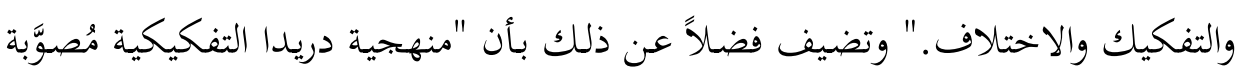

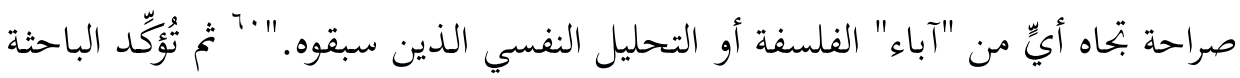

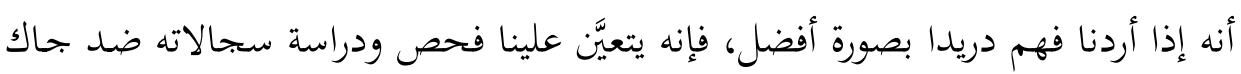
به باختصار، المدراش هو التفسير اليهودي التقليدي للتوراة، في حين أن التلمود هو بحموع الشرائع والتعاليم اليهودية. ${ }^{57}$ Handelman, The Slayers of Moses, p.171.

${ }^{58}$ Ibid., p.171. هُ تُقُرُّر هاندلمان بصعوبة وتعقيد مهمة إثبات الخلفية اليهودية وتأثيرها حتى في العَلمانيين اليهود. ${ }^{60}$ Handelman, The Slayers of Moses, p.163. 
لاكان، المحلل النفسي والناقد الفرنسي المعروف، ولا سيما في نقاشهما ومناظرتما عن

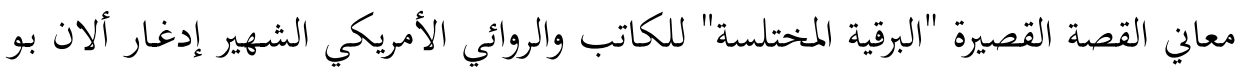
$7 \cdot(p) \wedge \leq q-11 \cdot q)$

فبـلاً مـن التـورُّط في قراءات وقراءات مضـادة معقـدة لا متناهيـة بـين الاثنـين، تقـترح الباحثة تناول موضوع القصة بوصفه يُشَِّص مسألة التأويل الحاخامي في مقابل التأويل

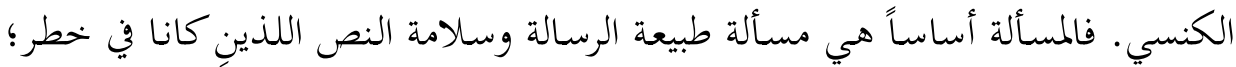

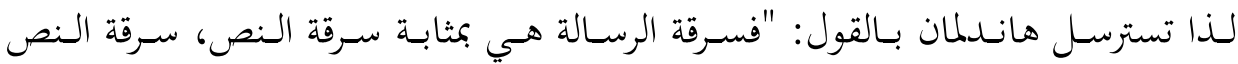

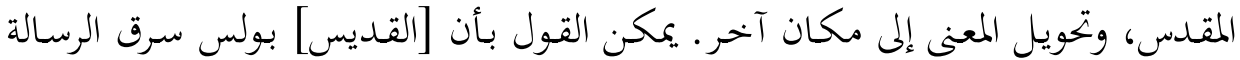

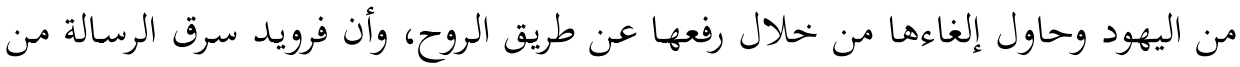

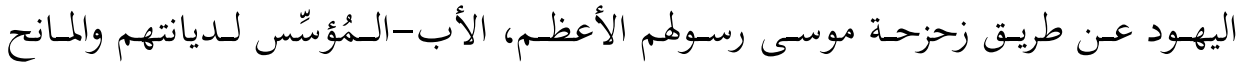

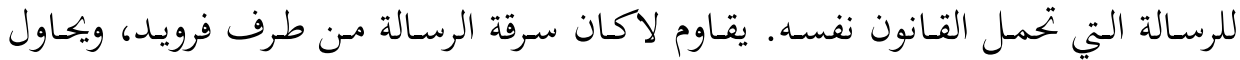

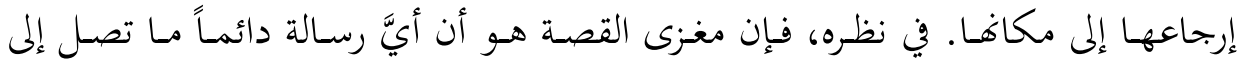

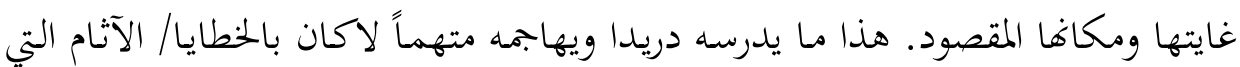

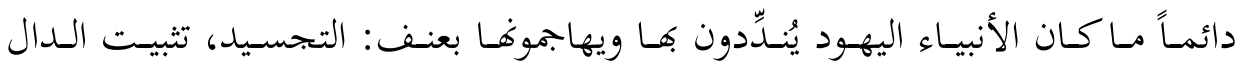
بالمدلول، وعبادة الأصنام...

في البَدُ كانت الكلمة ومعها كان الصراع؛ هذا ما تحاول هاندلمان تبيانه وتثبيته بدايةً

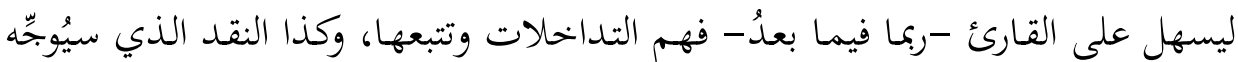

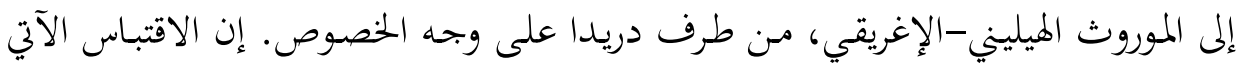

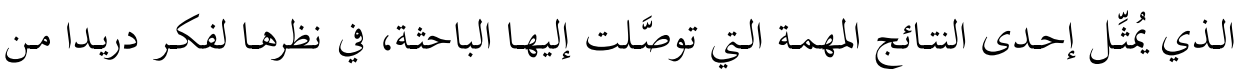

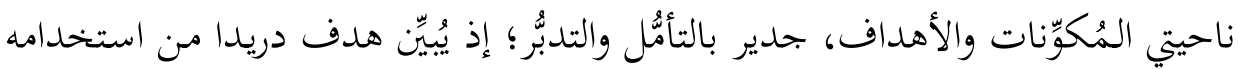
نظرية "الكتابة"، والتفكيك:

"مثل فرويد وبولس والمسيح Jesus، فبإن دريدا ورغم كل شيء مـا هـ إلا ابن مـن سلسلة الأبناء الضالين prodigal اليهود الذين يحاولون تخليد القانون من خحالال تجاوزاته

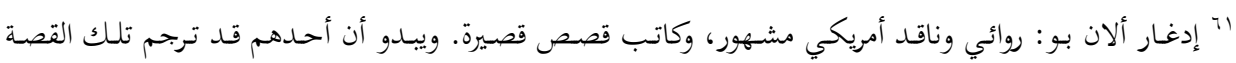
القصيرة باسم "الرسالة المسروقة"، وهي موجودة على الشبكة العنكبوتية.

${ }^{62}$ Handelman, The Slayers of Moses, p. 163. 
في كل تمرداته/انتهاكاته مركز نظرياتم. التفكيك الدريدي، كمـا التحليل النفسي، هو

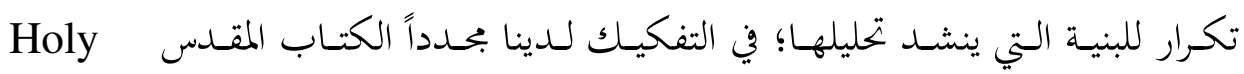

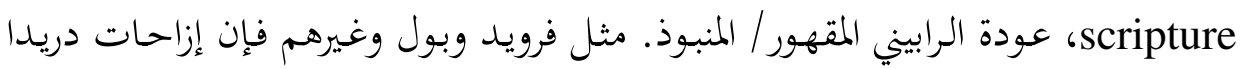
للآبـاء -السمُؤسِّين - النص $\}$ الكتـاب

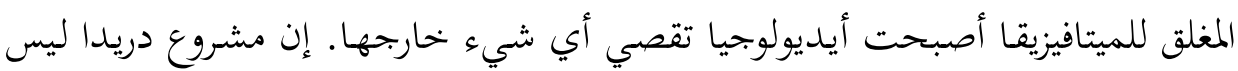

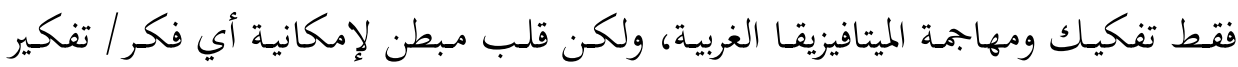

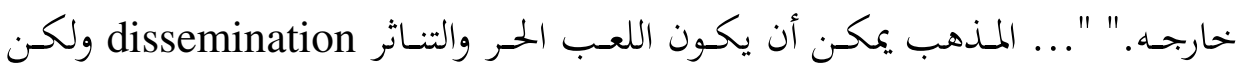

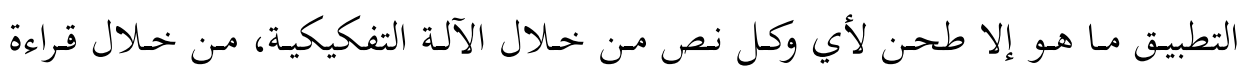

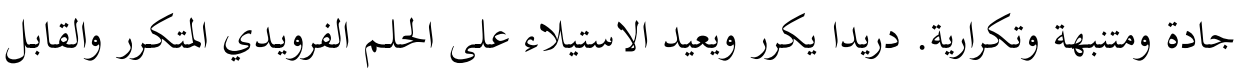

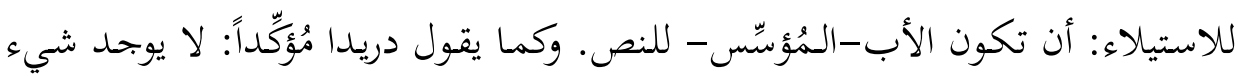

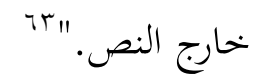

وعلى هذا، فالصراع حول الكتابة والتأويل له مُبرِّه الخاص وَفْق هذه الرؤية التي تشير

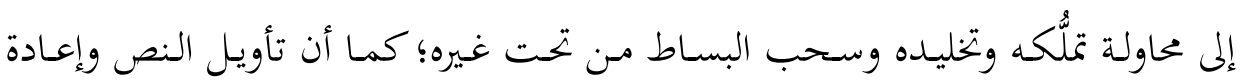
تأويله، بل تفجيره إلى ما لا يحصى من المعاني نقطة مركزية في هذا التقليد التأويلي. ربما

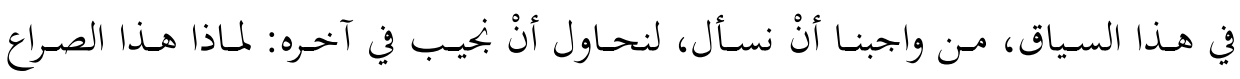

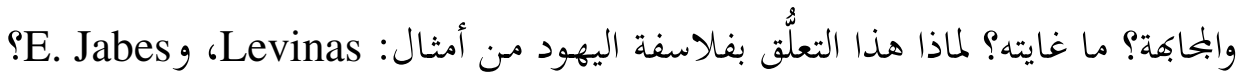
لماذا هـذا الصراع والتفكيك لحضـارة اللوغوس؟ لملاذا هـذا الإصـرار على المكتوب مقابل القول؟

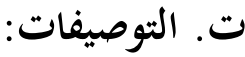

ترى هاندلمان أن نظرية دريدا عن الكتابة "تتجلّى بوضوح في الفصل الأول من عمله

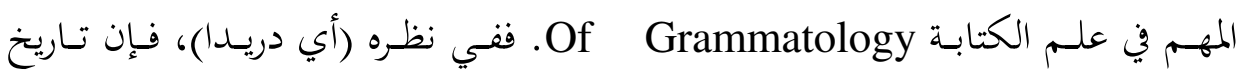

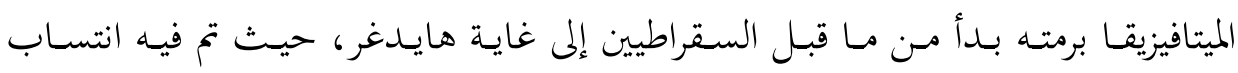

${ }^{63}$ Handelman, The Slayers of Moses, p. 166.

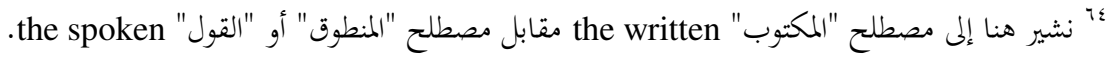




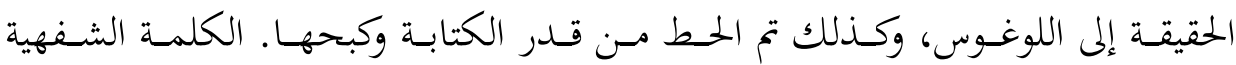

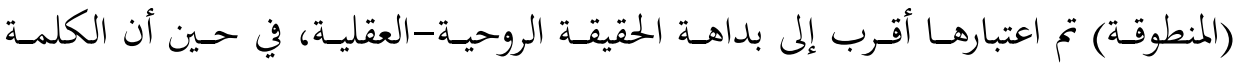

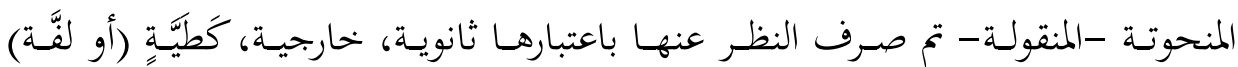

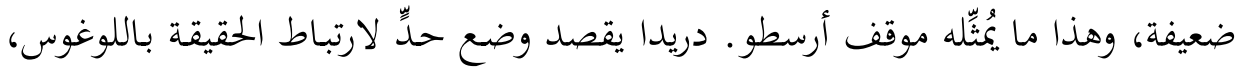

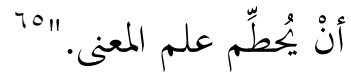

وتضيف هاندلمان بأن دريدا "مناظر (بحادل) عنيف، ماهر في تحريف وتحوير حجج محاوريه لتنسجم مع مطالبه، ولكن استخدامه الفريد الساخر لمقاطع وصفات (نعوت)

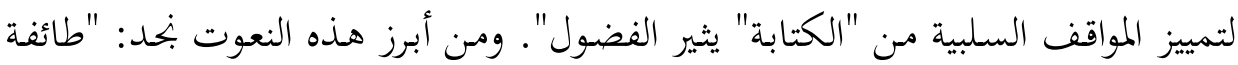

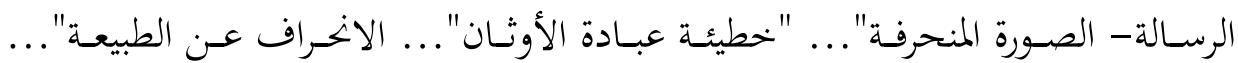

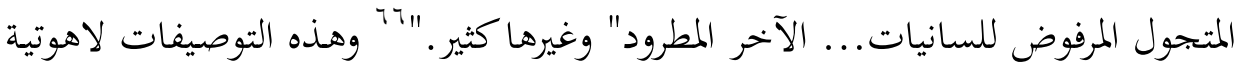

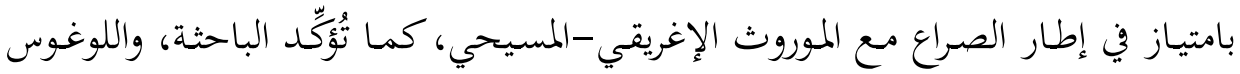

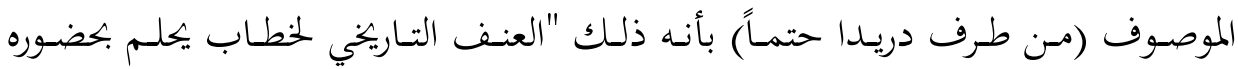
ووجوده الذاتي... اللوغوس الذي يعتقد نفسه بأنه سيد نفسه its own father، المرفوع

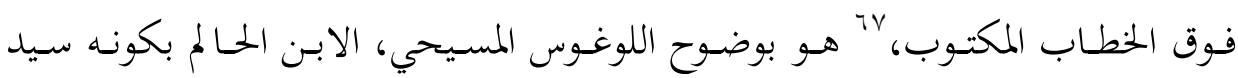
نفسه.

أمَّـا التوصـيفات مـن قبيـل: "المنفـي، المتتجـول، المتشـرد المـدان"، و"حامـل الرسـالة"،

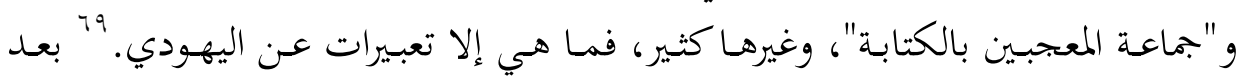

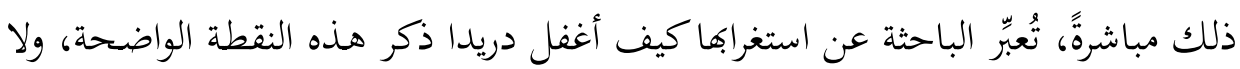

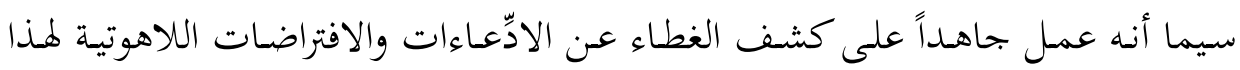

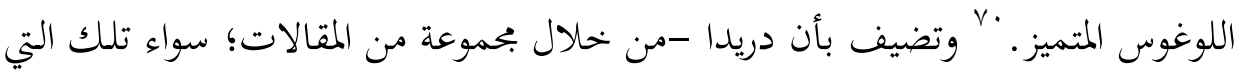

${ }^{65}$ Handelman, The Slayers of Moses, p. 167.

${ }^{66}$ Ibid., p. 169.

"آ الاقتباس هنا لدريدا مأخوذ من طرف هانسلمان من كتابه "علم الكتابة" Of Grammatology، الصفحات

${ }^{68}$ Handelman, The Slayers of Moses, p. 169.

(rq-ro)

${ }^{69}$ Ibid., p. 169.

${ }^{70}$ Ibid., p.169. 


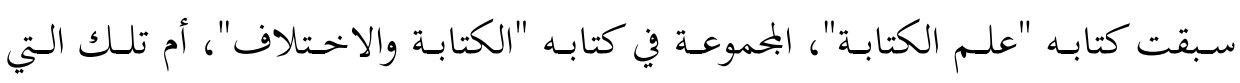

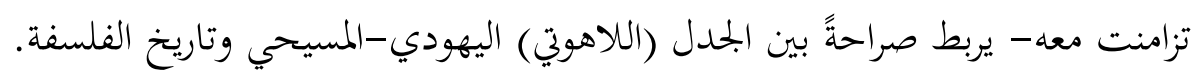

\section{r. قراءة في دراسة إليوت ر. وولفسون:}

\section{أ. تعريف بالباحث وأهمية الدراسة:}

وُلِلد الباحث إليوت وولفسون في نوفمبر عام 901 1م، وكان ميدان اهتمامه الرئيس هو

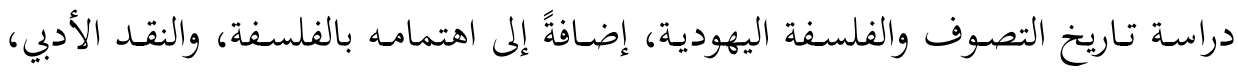
ونظرية الخطاب النسوي، وألَّف العديد من الكتب والمقالات القيمة في هذه الموضوعات.

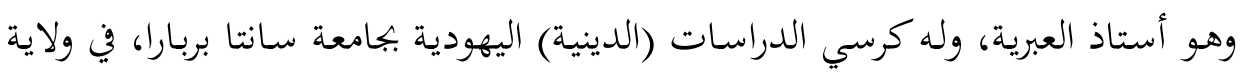
كاليفورنيا الأمريكية.

يكشف وولفسون، في هذه الدراسة، جانباً مهماً من فكر دريدا في علاقته بالحكمة الباطنية للقبالة التقليدية، في مقارنة يعرضها عمل دريدا نفسه الذي يتوسَّل في مناسبات

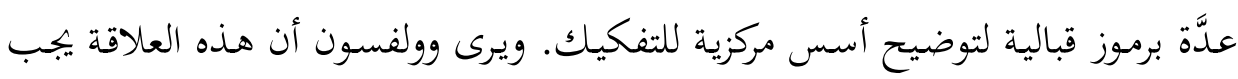

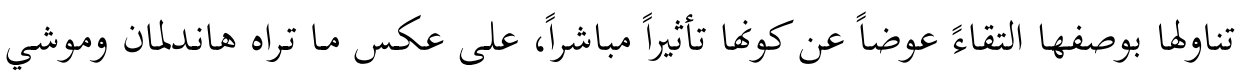

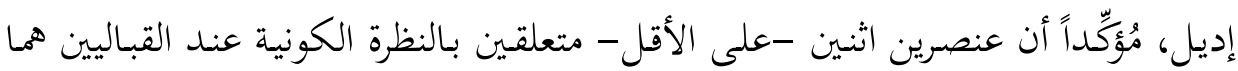

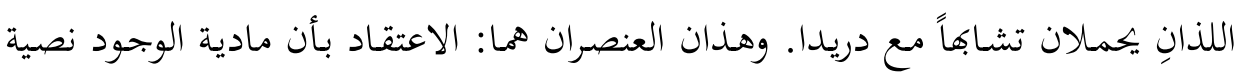

${ }^{71}$ Wolfson, Eliot. "Assaulting the Border: Kabbalistic Traces in the Margins of Derrida", Journal of the American Academy of Religion, Vol.70, No.3, Sep. 2002, pp. 475-514.

$$
\text { L لمعرفة المزيد عنه، وتعرُّف أهم منشوراته، تصفَّح الرابط الآتي: Vr }
$$

- http://www.religion.ucsb.edu/people/faculty/elliot-wolfson /

$$
\text { يناقش وولفسون موضوع دريدا والقبالة وغيرها في كتب أخرى صدرت له، مثل: }
$$

- Language, Eros, and Being: Kabbalistic Hermeneutics and the Poetic Imagination, Fordham University Press, 2005.

- Venturing Beyond: Law and Morality in Kabbalistic Mysticism, Oxford University Press, 2006.

- Luminal Darkness: Imaginal Gleanings from Zoharic Literature, Oneworld Publications, 2007. 
(نصية الوجود)، والدور الخاص المُّحصَّص للتتراجرامـاتون tetragrammaton (الاسم

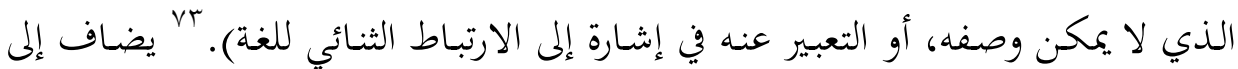

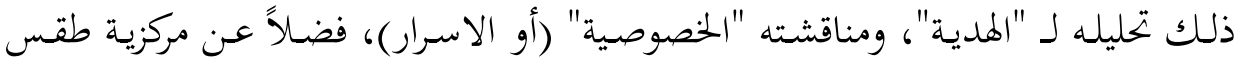
(شعيرة) الخِتان في كتابته.

تلكـم -إذن- أربعـة عناصـر تقـارب بـين دريـا والقبـاليين. ولكـن، بـالرغم مـن هـذه

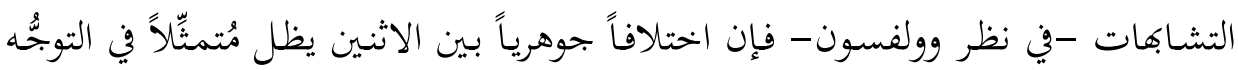

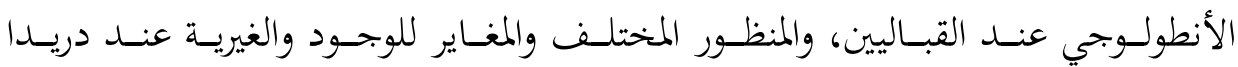

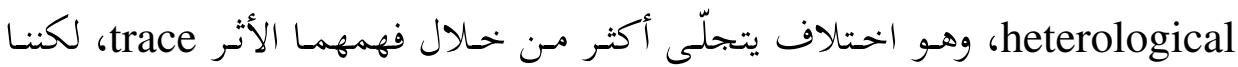

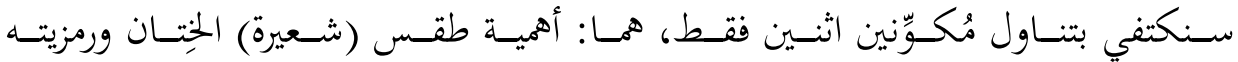
Circumcision ب. أهمية طقس المَتِان ورمزيته:

يعود دريدا في عدد من كتاباته إلى الكلام عن الخِتان بوصفه شعيرة لما قيمتها الحرفية والدلالية الاستعارية؛ فهو -بحسب وولفسون- القطع البدئي الذي يربط بصورة تقليدية

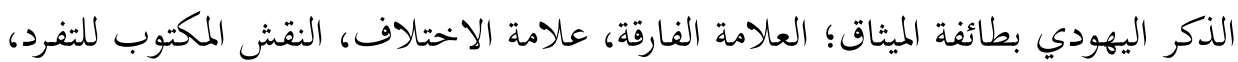
اسم علم -أو الاسم- الذي يمكن نطقه مَرَّة واحدة فقط. فقطع الحِنتان يراه دريدا تمثيلاً للذات المتعلقة بسيرة المرء الذاتية؛ لأنه أشبه بالخناتم المزدوج الإثبات، فهو فئم إطار ودائرة

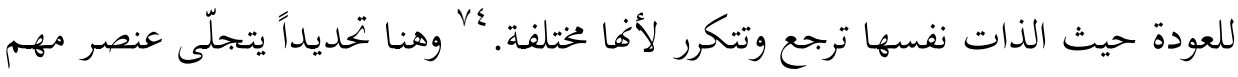

${ }^{73}$ Wolfson, Eliot. "Assaulting the Border: Kabbalistic Traces in the Margins of Derrida," Journal of the American Academy of Religion, Vol.70, No.3, Sep. 2002, p. 475.

بالعودة إلى موسوعة عبد الوهاب المسيري على الشبكة، فإننا بحد التعريف الآتي: "تتراجراماتون" كلمة إغريقية بمعنى

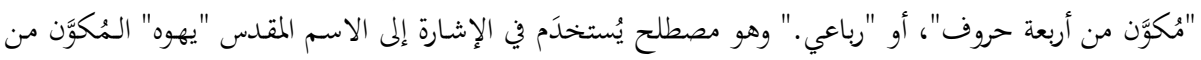

$$
\text { أربعة أحرف. }
$$

http://www.elmessiri.com/encyclopedia/JEWISH/ENCYCLOPID/MG5/GZ2/BA01/M D08.HTM.

${ }^{74}$ Wolfson, "Assaulting the Border: Kabbalistic Traces in the Margins of Derrida," p. 494. 
يربط جانباً من تفكير دريدا بالرمزية القبالية: الصلة بين المِتِان والكتابة المنقوشة، هوإزالة

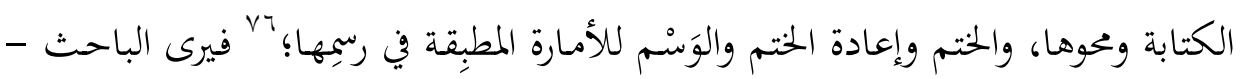
مثلمـا اقـترح في عـدد مـن دراسـاته- أن الممارسـة التطبيقيـة القباليـة تُعـنى بالـذكر المختـون الذي يجِب سَتْره في انكشافهِ.

فسَتْر الـذكر، في المعرفـة التقليديـة القباليـة، على أسس أخحلاقيـة، قـام بوظيفـة الأسـاس الشعائري للتأويل الرمـزي للخِتـان؛ بَمسيداً للعـب الهرمنوطيقي للسـية، فمـا بَطنَ واستَترَ يُفْشَى ويُباح لأولئك الذين هم خانعون؛ لأكم يعلمون فن سَتْر الكتمان عن طريق إفشاء الكشف. وعلى هذا، "يمكن اعتبار اللخِتان بمثابة الطقس والسر المقدس الذي من خلاله يلعب اليهودي دور الإخفاء والخداع عن طريق قطع القُلْفَة حتى يُحرِّر وينقُش رمز ورسم

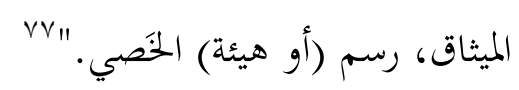

فتنصيص الجمسد؛ أي أنْ يصير الجمسد نصاً بفعل الكتابة، يرتبط عند دريدا كما عند

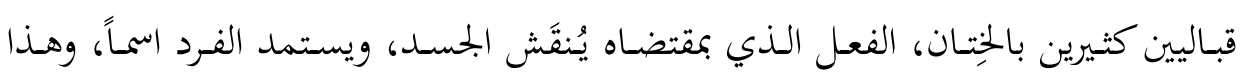
الطقس اليهودي هو ما حافظ عليه دريدا.

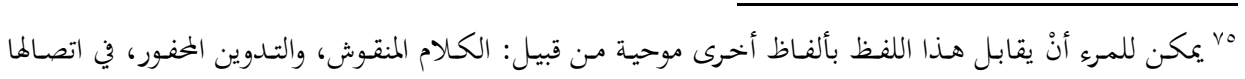

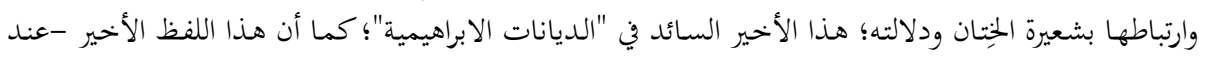

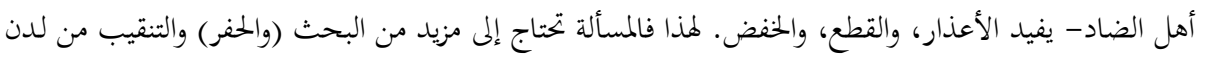

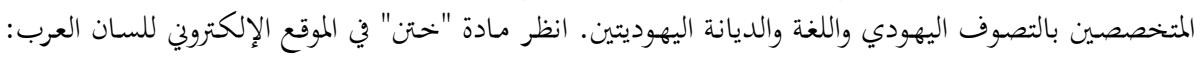
/ ختن /http://www.lesanarab.com/kalima

${ }^{76}$ Wolfson, “Assaulting the Border: Kabbalistic Traces in the Margins of Derrida,” p. 494.

${ }^{77}$ Ibid., p.494.

هذا الاقتباس (رسم (أو هيئة) الخُصي) مُستمَدُّ من مؤلَّف دريدا الآتي الذي يبدو أشبه بالسيرة الذاتية، وقد عدنا إليه

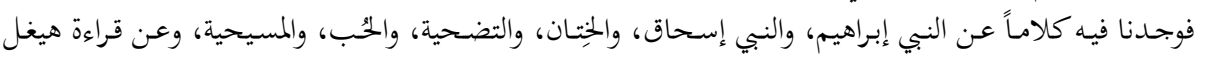
وتأويله:

- Derrida, Jacques. Glas, Trans: John Leavey: and Richard Rand, London:

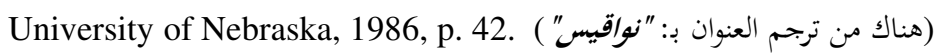

${ }^{78}$ Wolfson, "Assaulting the Border: Kabbalistic Traces in the Margins of Derrida," p. 498. 
من جانب آخر، وعلى نهوِ يتناغم مع القباليين، يقترح دريدا أن "القطع أو البتر الحريف

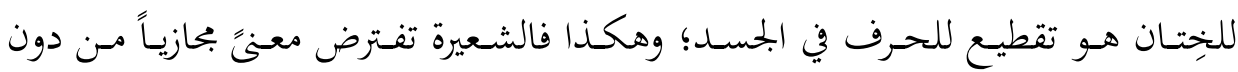
الانتقاص من معناها الملموس؛ يتم تحويل الواقعية الجسمدية بطريقة شبيهة بما يجائد المرع في

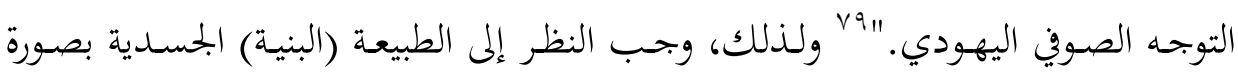
سيميائية كأها مشكلة من حروف؛ إذ يرى القباليون أن حروف الأبجدية العبرية الاثنتين

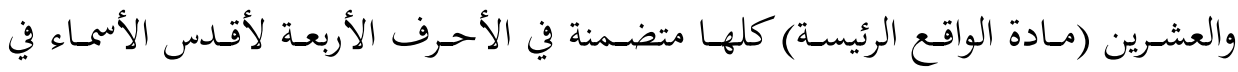

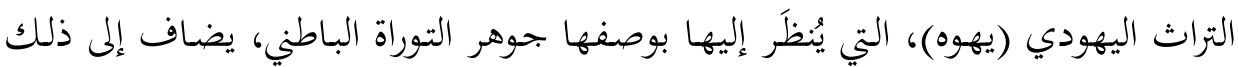

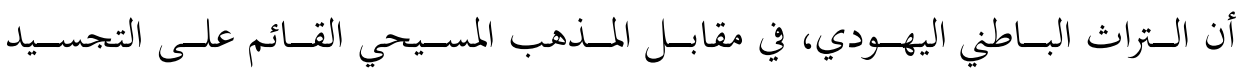
الادئ incarnation $\wedge$.

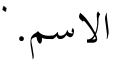

فبـالرغم مـن أن دريدا لا يعتنق الفكرة القبالية بصـورة كلية، وبكل تعقُّدها الرمزي،

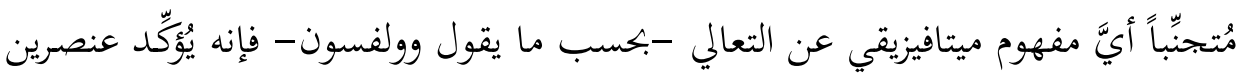

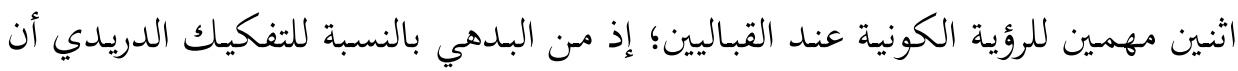

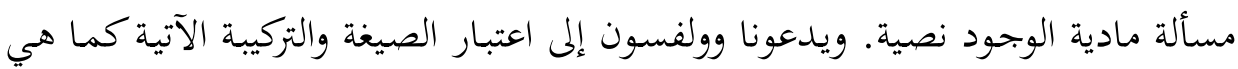

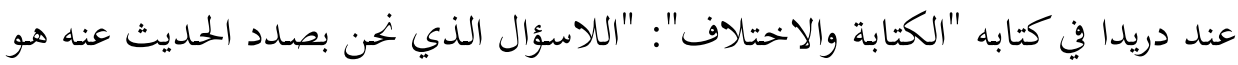

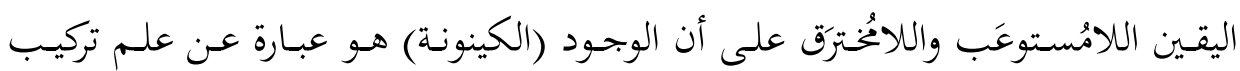

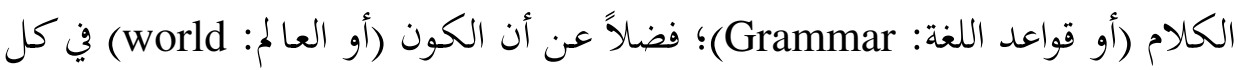

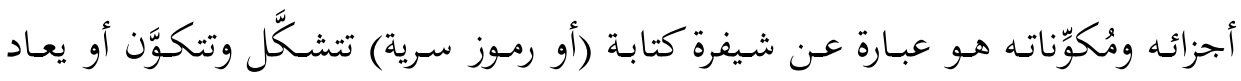

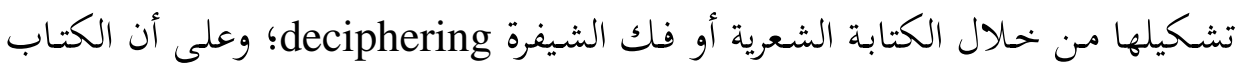

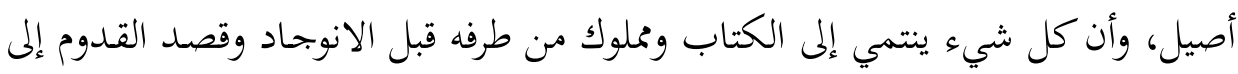

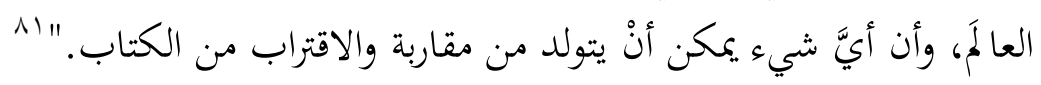

${ }^{79}$ Ibid., p.495.

${ }^{80}$ Ibid., p.495.

والمقطع أسفله هو المترجم أعلاه .

"The nonquestion of which we are speaking is the unpenetrated certainty that Being is a Grammar; and that the world is in all its parts a cryptogram to be constituted or reconstituted through poetic inscription or deciphering; that the book is original, that 
فأهمية الكتاب وأوَّليته مهمة في هذا الخصوص؛ إذ يقول وولفسون إن وضع الكتاب

في المقدمة (في المقام الأول) لا يعني أنه ارتد إلى افتراض متمركز حول اللوغوس لأصل ما

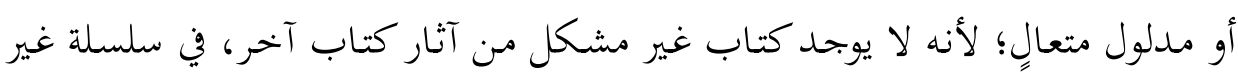
متناهية من الدلالات. وباختصار، فإن "الاستهلال بالكتاب هو بالتالي تفويض التأويل باعتباره الاستثارة الأولية"، أو كمـا يُقِرّرهـا دريدا بنفسهـ: "ضرورة التعليق، مثل الضرورة

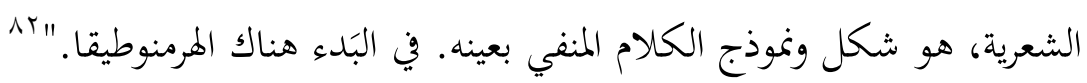

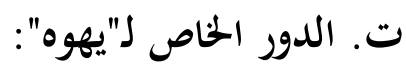

يتصل التشابه الثاني مع القبالة التقليدية، ويرتبط بالدور الخاص الذي يعزوه دريدا إلى

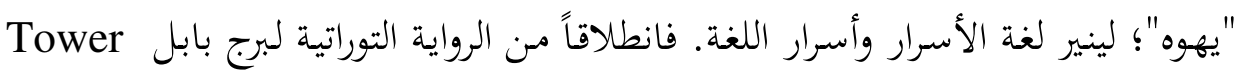
of Babel

everything belongs to the book before being and in order to come into the world; that anything can be born only by approaching the book, can die only by failing insight of the book; and that always the impassible shore of the book is first". See:

- Derrida, Jacques. Writing and Difference, Trans: With an Introduction and additional notes by Alan Bass. London and New York: Routledge and Kegan Paul Ltd. 1978, pp, 76-77.

أخذذ وولفسون هذا المقطع -الذي كتبه دريدا في الأصل فصلاً ثالثاً بعنوان: "إدموند جابيس وسؤال الكتاب"- من

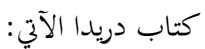

- Writing and Difference. Trans: by Alan Bass. Chicago: University of Chicago Press, 1978, pp. 76-77.

- L'Écriture et la différence, Paris Éditions du Seuil, 1967, p. 114.

$$
\text { ويكن الرجوع إلى النص الفرنسي: }
$$

$$
\text { ويكن أيضاً الرجوع إلى الاقتباس وغير ذلك من الإشارات والصيغ عند دريدا في الكتاب المترجم إلى الإنحليزية: }
$$

-Derrida, Writing and Difference, Ibid.

${ }^{82}$ Wolfson, "Assaulting the Border: Kabbalistic Traces in the Margins of Derrida," p. 496. See also:

- Derrida, Writing and Difference, p. 81.

وتوجد أيضاً إشارات إلى الشعراء، والأحبار، والتعاليه، والألواح المكسرة في الصفحة نفسها من هذا الكبات الكتاب.

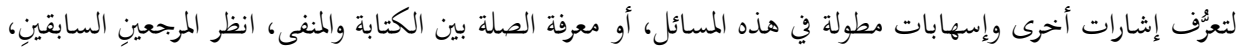
أو كتاب جدعون (أو جيدون) أوفرات الآتي:

- Ofrat, Gideon. In Praise of Exile, Jerusalem: Karta, 2000. 
تصبح الترجمة ضرورية ومستحيلة، مثل تأثير الصراع من أجل اكتساب الاسم، ضرورية

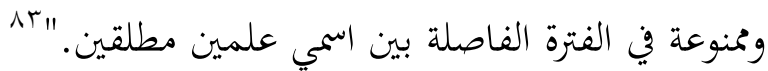

ومن تَمََّ، يوصَف التتراجراماتون بأنه الاسم الذي يمكن ترجمته، والذي تستحيل ترجمته،

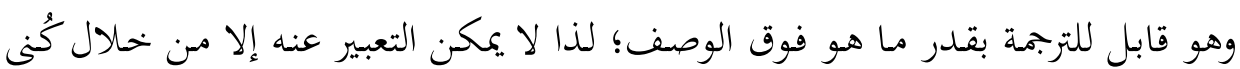

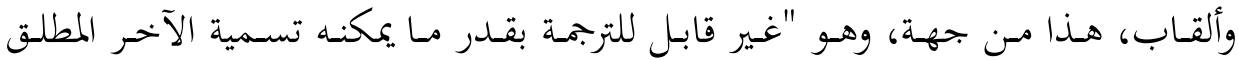

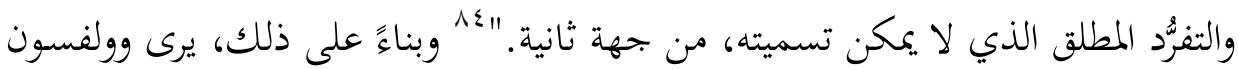

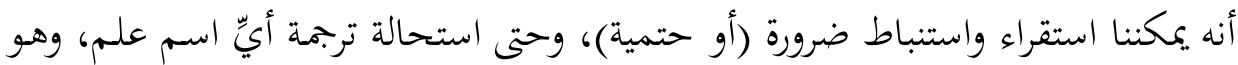

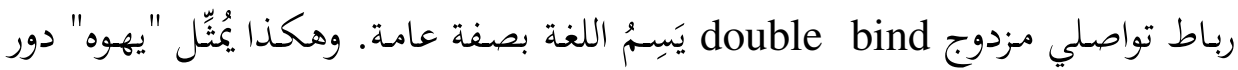

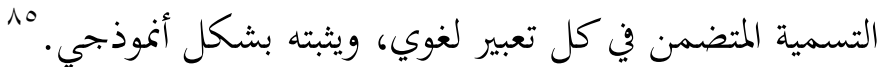

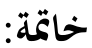

عرضنا في هـا البحتث صـلات التقاء جانب مهم مـن فكر دريدا مع الفكر القبالي

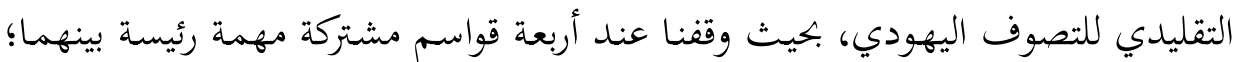

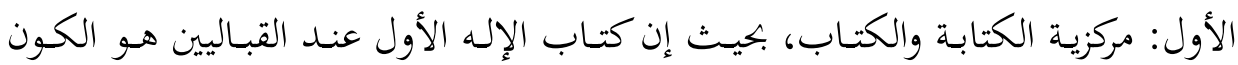

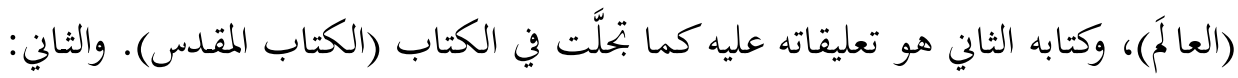

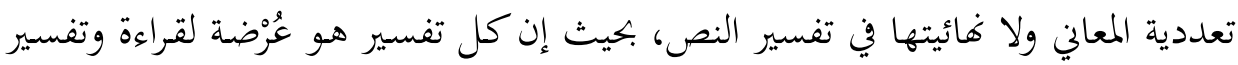

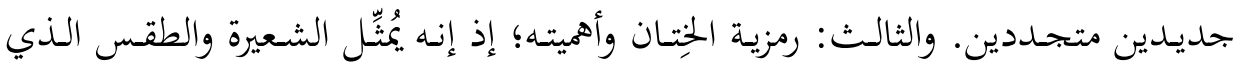

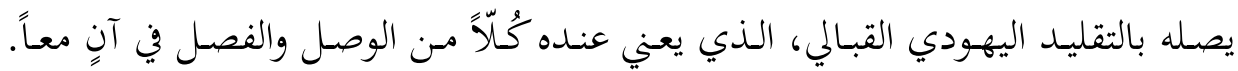

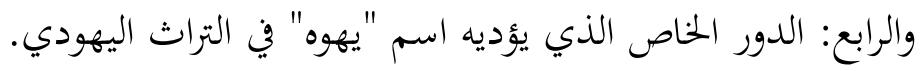

${ }^{83}$ Wolfson, "Assaulting the Border: Kabbalistic Traces in the Margins of Derrida," p. 496.

$$
\text { الاقتباس الذي اعتمده وولفسون هنا هو من دراسة دريدا في الكتاب الآتي: }
$$

- "Des Tours de Babel", Trans. Joseph F. Graham, In: Difference in Translation, 165207, Ed. by Joseph F. Graham. Ithaca, NY: Cornell University Press, 1985, P. 170.

${ }^{84}$ Wolfson, "Assaulting the Border: Kabbalistic Traces in the Margins of Derrida," p. 497.

${ }^{85}$ Ibid., p.497. 


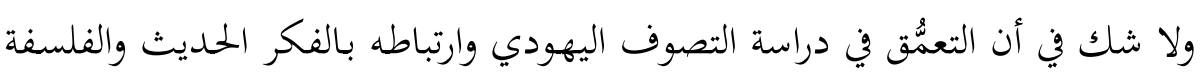

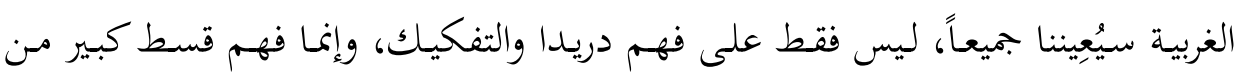

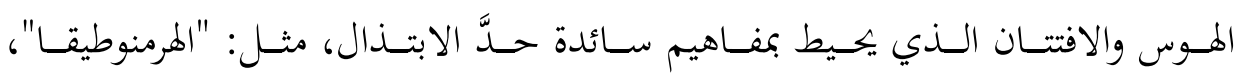

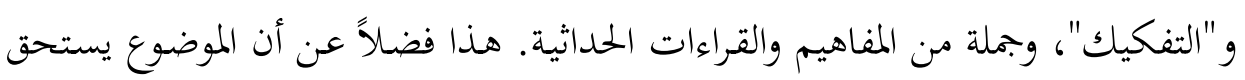

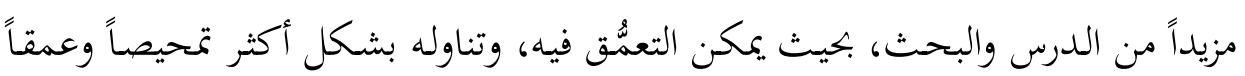

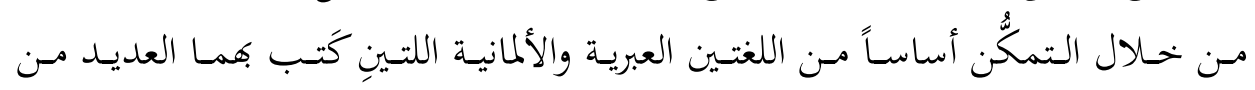

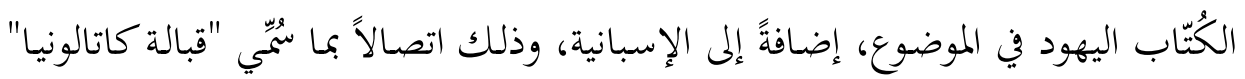
في شمال إسبانيا. وختاماً، فبإن نظرية دريدا الخاصة بالكتابة، واستعماله مفاهيم ذات صلات بات لاهوتية

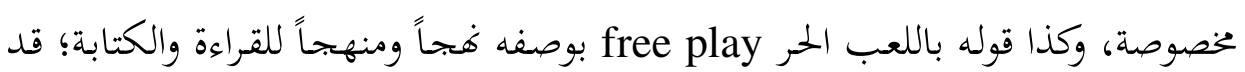

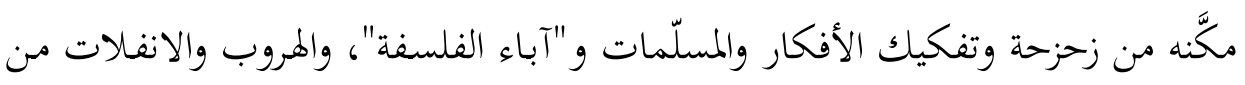

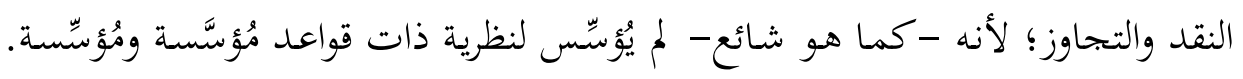

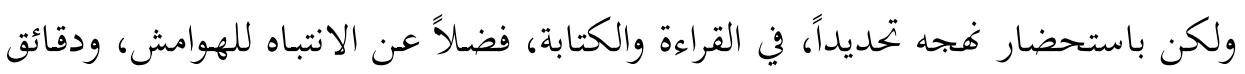

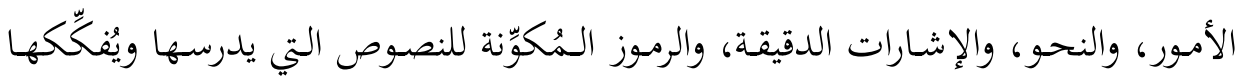

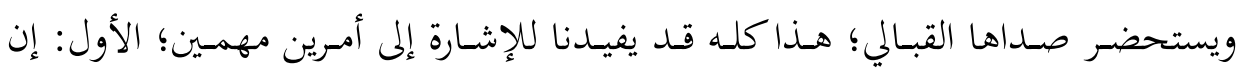

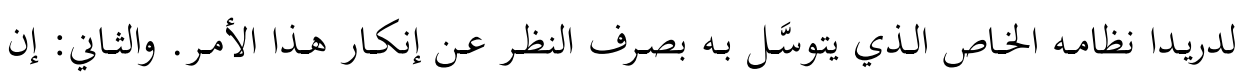

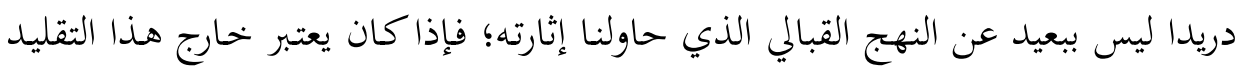

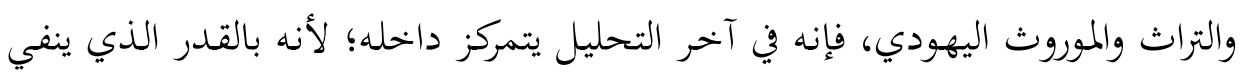

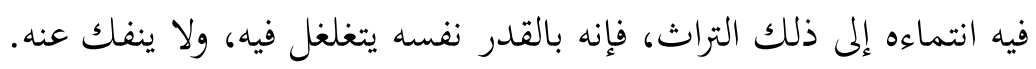

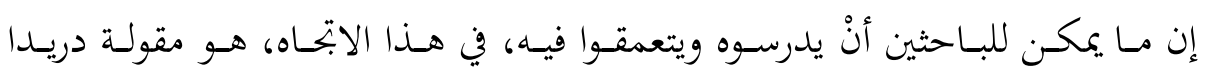
الرئيسة: "لا يوجد شيء خارج النص"، وهي مقولة مركزية عند القباليين. 